\title{
Petrologia do corpo máfico-ultramáfico da Fazenda Campo do Meio, Marcionílio Souza (Bahia, Brasil)
}

\author{
(este artigo contém material suplementar disponível na versão eletrônica)
}

\author{
Andreia Gonçalves de Araújo Nunes RANGEL \& Angela Beatriz de MENEZES LEAL
}

Programa de Pós-graduação em Geologia, Universidade Federal da Bahia. Rua Barão de Jeremoabo s/n, CEP 40170-290, Ondina, Salvador, Brasil (E-mail: andreianrangel@gmail.com, angelab@ufba.br).

Resumo. O corpo máfico-ultramáfico da Fazenda Campo do Meio, no município de Marcionílio Souza, é caracterizado como um lopólito assimétrico com dimensões de 1300 × 500 m e orientação WSW-ENE. Geotectonicamente, está localizado no Cráton São Francisco, intrudindo a encaixante granulítica do Bloco Jequié. Esse estudo descreve petrograficamente o corpo e analisa o seu comportamento magmático, a partir de análises de rocha total e química mineral. O corpo é constituído por peridotitos, piroxenitos e hornblendito, além de rocha máfica anfibolitizada. Os litotipos ultramáficos apresentam graus variados de serpentinização, entretanto, as texturas primárias estão preservadas, possibilitando o reconhecimento dos minerais ígneos. A paragênese da porção ultramáfica é representada por forsterita/crisólita, espinélio, enstatita, augita e magnésio-hornblenda. Na porção máfica, a deformação foi mais expressiva com paragênese de magnésio-hornblenda, labradorita e diopsídio. Os diagramas de variação de elementos maiores, traço e terras raras demonstram que, apesar dos eventos pósmagmáticos que afetaram o corpo, não houve interferência significativa no quimismo original, o qual apresenta olivina e ortopiroxênio como as principais fases controladoras do fracionamento magmático. Ademais, a partir dos dados litoquímicos, o corpo é caracterizado como uma intrusão de natureza toleítica continental e apresenta afinidade com magmas komatíticos. A geotermobarometria sugere que a temperatura de cristalização da porção ultramáfica, calculada em augita, foi de 1175,6 a $1249,5^{\circ} \mathrm{C}$ e a temperatura de reequilíbrio metamórfico do anfibolito em par anfibólio-plagioclásio foi de $869^{\circ} \mathrm{C}$ com pressão em torno de 4 a $4,5 \mathrm{kbar}$, compatível com os dados bibliográficos de pressão para as rochas encaixantes granulíticas.

Palavras-chave. cumulado, toleítos, Cráton do São Francisco

\begin{abstract}
The mafic-ultramafic body of Fazenda Campo do Meio, in the municipality of Marcionílio Souza, is characterized as an asymmetric lopolith with dimensions of $1300 \times 500 \mathrm{~m}$ and WSW-ENE orientation. Geotectonically, it is located in the São Francisco Craton, intruding on the granulitic embasement of the Jequie Block. This study describes petrographically the body and analyzes its magmatic behavior, based on whole-rock chemical analysis and mineral chemistry. The body consists of peridotites, pyroxenites and hornblendite, as well as mafic rocks amphibolitized. The ultramafic lithotypes present varying degrees of serpentinization. However, the primary textures are preserved, enabling the recognition of igneous minerals. Paragenesis of the ultramafic portion is represented by forsterite/chrysolite, spinel, enstatite, augite and magnesium-hornblende. In the mafic portion, the deformation was more expressive with magnesium-hornblende, labradorite and diopside paragenesis. The diagrams of variation of major elements, trace and rare earths demonstrate that, despite the post-magmatic events that affected the body, there was no significant interference in the original chemism, which present olivine and orthopyroxene as the main controlling phases of the magmatic fractionation. In addition, from the lithochemical data, the body is characterized as an intrusion of continental tholeitic nature and has an affinity with komatiitic magmas. Geothermobarometry suggests that the crystallization temperature of the ultramafic portion, calculated in augite, was 1175.6 to $1249.5^{\circ} \mathrm{C}$ and the metamorphic rebalance temperature of the amphibolite in amphiboleplagioclase pair was $869^{\circ} \mathrm{C}$ with pressure around 4 to 4, $5 \mathrm{kbar}$, compatible with bibliographic pressure data for granulitic basement rock.
\end{abstract}

Keywords. cumulates, tholeiitic, São Francisco Craton 


\section{Introdução}

A maioria das rochas ultramáficas encontradas na crosta formou-se a partir da cristalização fracionada de magmas básicos em câmaras magmáticas (Bucher \& Frey, 1994). Pesquisas relacionadas às rochas máficas e ultramáficas revelam características importantes sobre a gênese de magmas basálticos e indicam ambientes geotectônicos à época de sua formação (e.g. Campbell, 1996; Ernst, 2007; Bryan \& Ernst, 2008; Menezes Leal et al., 2012; Winter, 2014; Namur et al., 2015). O estudo de sua natureza e distribuição em porções continentais é de extrema relevância para reconstituição de ambientes geotectônicos, assim como o entendimento dos processos magmáticos atuantes.

No geral, esses corpos foram envolvidos em um ou mais eventos tectônicos de deformação e metamorfismo que substituem significativamente a mineralogia primária. Entretanto, a maior parte dessas rochas ainda preservam texturas e estruturas originais (Oliveira \& Knauer, 1993).

Os principais corpos máfico-ultramáficos do estado da Bahia estão encaixados no embasamento arqueano-paleoproterozoico do Cráton do São Francisco. Grande parte desses corpos é estratiforme, de natureza toleítica e hospeda depósitos minerais de $\mathrm{Cr}$ (e.g. Couto et al., 1978; Marques \& Ferreira Filho, 2003), sulfetos de Cu e Ni (e.g. Abram, 1993; Ferreira Filho et al., 2013) e Fe, Ti, V (e.g. Brito, 2000; Moraes \& Veiga, 2008).

O presente artigo apresenta a caracterização petrográfica, químicomineralógica e litoquímica do corpo máficoultramáfico da Fazenda Campo do Meio, município de Marcionílio Souza, Bahia, a partir de estudos petrográficos somados à análise química de rocha total de elementos maiores, traço e terras raras, além de química mineral, buscando-se ampliar o conhecimento geológico relacionado às rochas máficas e ultramáficas arqueano-paleoproterozoicas do Cráton do São Francisco.

\section{2 Área, materiais e métodos}

\section{1 Localização da área}

A área de estudo está localizada no município de Marcionílio Souza, região centro-oriental do estado da Bahia, distando, aproximadamente, $330 \mathrm{~km}$ da capital do estado.

Geotectonicamente, está situada no Cráton São Francisco, entidade consolidada a partir da colisão de antigos segmentos crustais, o Bloco Gavião, Jequié, Serrinha e o cinturão ItabunaSalvador-Curaçá (ISC) durante o Ciclo Orogênico Paleoproterozoico (Barbosa \& Sabaté, 2002, 2003, 2004), formando a porção setentrional do embasamento do Cráton São Francisco (Fig. 1A) (Almeida, 1977).

O Bloco Jequié (Fig. 1B), região onde está inserido o corpo rochoso, está situado na porção SSE do Cráton do São Francisco, entre o Bloco Gavião, a leste, e o cinturão ItabunaSalvador, a oeste. É composto por rochas mesoneoarqueanas como granulitos heterogêneos orto e paraderivados, anfibolitos intercalados com rochas quartzo-feldspáticas, granulitos enderbito-charnockíticos, granulitos augencharnockíticos e granitoides. Como unidades paleoproterozoicas, ocorrem charnockitos em estruturas dômicas, além de rochas gabroanortosíticas e dunítica-peridotíticas (Barbosa et al., 2012; Santos, 2013, 2018).

De forma geral, os principais lineamentos, localizados no extremo leste, apresentam trend NNE na porção meridional com deflexão no sentido norte, formando um grande arco com concavidade voltada para oeste (Sá et al., 2010). Os eventos paleoproterozoicos que atingiram o Bloco Jequié transpuseram grande parte das suas estruturas, obliterando registros de eventos anteriores (Barbosa et al., 2003; Barbosa \& Sabaté, 2002, 2003, 2004), todavia, as deformações foram de menor intensidade, comparadas às estruturas do ISC, onde é possível observar dobras recumbentes fechadas, horizontais e simétricas com dobras parasíticas (S, Z e M/W). As charneiras dessas dobras orientam-se, em geral, na direção sul com mergulhos entre 10 e $16^{\circ}$ para NNE. Em alguns locais, as dobras 
recumbentes iniciais foram completamente obliteradas pelas deformações da segunda fase, sobretudo pelas transcorrências de natureza transpressiva sinistral, formando dobras amplas, com planos axiais verticalizados e orientados, em geral, na direção N-S (Barbosa et al., 2012). Seus limites com as unidades adjacentes estão, comumente, marcados por descontinuidades estruturais. Os contatos com o Bloco Gavião, a noroeste, são assinalados por zonas de cisalhamento transpressional dextral de direção NW-SE e, com o Cinturão Itabuna-Salvador Curaçá, por zonas de cisalhamento e falhas de empurrão com vergência geral para leste.

Dados isotópicos obtidos em granulitos básicos, pertencentes à unidade dos granulitos heterogêneos, exibem idade $T_{D M}$ de 3,29 Ga e $\varepsilon N d$ igual a -24,4 (Marinho et al., 1992). Nos granulitos heterogêneos, a partir do método Rb-Sr e seis isócronas de afloramentos, foram obtidas idades médias entre 2,65 a 2,7 Ga com Sr entre 0,7021 a 0,7101, respectivamente (Mascarenhas \& Garcia, 1989). Essas idades foram confirmadas com sete isócronas $\mathrm{Rb}-\mathrm{Sr}$ de referência que ficaram em torno de 2,7 Ga. Datações $\mathrm{Pb}-\mathrm{Pb}$ em monazita no charnockito dômico, exibem idades de 2,05 a 2,03 Ga, sugerindo que esta rocha foi reequilibrada após ou próximo ao pico metamórfico paleoproterozoico (Barbosa et al., 2004, 2006).

No Bloco Jequié há uma série de corpos de natureza gabro-anortosítica (e.g. Cruz, 1989; Macêdo, 2000) e dunito-peridotítica (Santos, 2013, 2018), de dimensões inferiores a $100 \mathrm{~km}^{2}$ (Menezes Leal et al., 2012), onde muitos desses corpos carecem de estudo. O corpo máficoultramáfico da Fazendo Campo do Meio tem geometria similar a um lopólito assimétrico apresentando $1300 \mathrm{~m} \times 500 \mathrm{~m}$ e com orientação WSW-ENE. Exibe, no geral, estratigrafia com predominância de rochas ultramáficas próximas à superfície e rocha anfibolítica, de protólito máfico, em profundidade. Em mapa, entretanto, é possível observar as unidades do corpo em contato lateral, onde o anfibolito predomina na porção norte e os peridotitos na porção sul como demonstrado no mapa da figura 2.

\subsection{Métodos analíticos}

Informações de campo foram obtidas através de reconhecimento geológico. Contudo, a obtenção dos dados resultou de descrição sistemática de cinco testemunhos de sondagem realizados pela Pacific Imperial: CM01, CM02 e CM03 e pela Companhia Baiana de Pesquisa Mineral: $\mathrm{CMO}_{4}$ e $\mathrm{CM0} 5$ com orientações $000 / 50^{\circ}, 000 / 50^{\circ}, 000 / 60^{\circ} 180 / 60^{\circ}$ e $180 / 60^{\circ}$, respectivamente. Entretanto, apenas os testemunhos 4 e 5 foram utilizados para representar a estratigrafia do corpo, visto que os demais furos estão paralelos ao acamamamento.

Foram confeccionadas 47 lâminas delgadas: 2 do embasamento e 45 do corpo máfico-ultramáfico. Para estudos petrográficos e litoquímicos, foram selecionados locais representativos, de acordo com a variação litológica, a mineralogia, as feições ígneas preservadas, além das alterações secundárias observadas. Para a petrografia, foi utilizado o microscópio OLYMPUSBX41 do Laboratório de Microscopia Óptica da Universidade Federal da Bahia.

Apesar do metamorfismo incipiente observado nos litotipos da unidade ultramáfica, na classificação, a partir da composição modal, foi empregado o diagrama Olivina - Ortopiroxênio - Clinopiroxênio (Ol-Opx-Cpx) para os peridotitos e piroxenitos e o diagrama Olivina - Ortopiroxênio \pm Clinopiroxênio - Horblenda (Ol - Opx $\pm \mathrm{Cpx}-\mathrm{Hbl}$ ) para o hornblendito, conforme Streckeisen (1976) e Le Maitre et al. (2002). Para a porção máfica, onde o metamorfismo e deformação foram mais expressivos, foi utilizada a nomenclatura para rocha metamórfica de Coutinho et al. (2007), ambas recomendadas pela International Union of the Geological Sciences (IUGS). A abreviação dos minerais está de acordo com Whitney \& Evans (2010).

$$
\text { Para a litoquímica, foram realizadas }
$$
43 análises na SGS-Geosol Laboratório Ltda, utilizando a técnica de ICP-OES (Inductively Coupled Plasma - Optical Emission Spectrometry) para elementos maiores e ICP-MS (Inductively Coupled Plasma - Mass Spectrometry) para os elementos traço. Os 


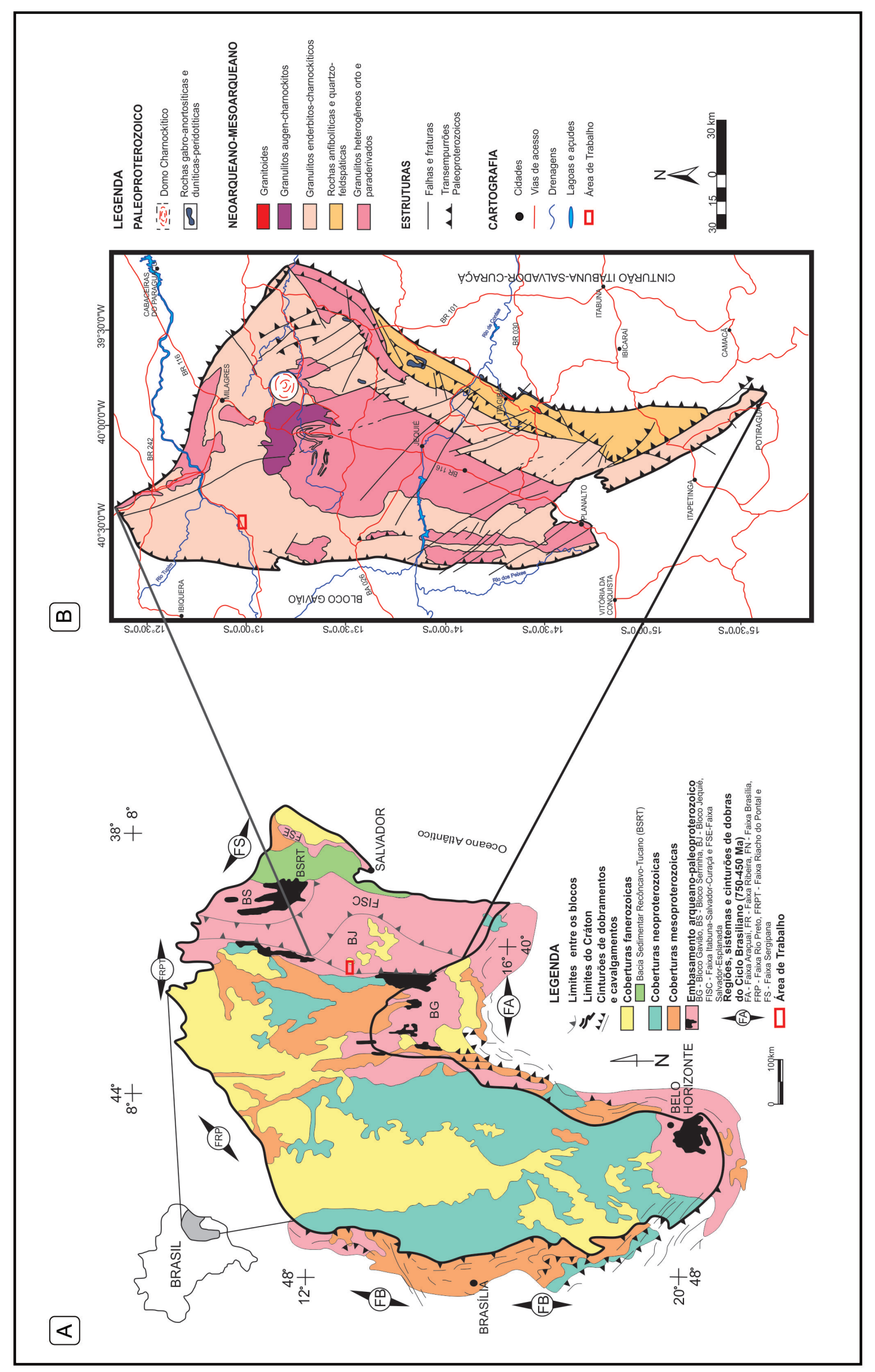

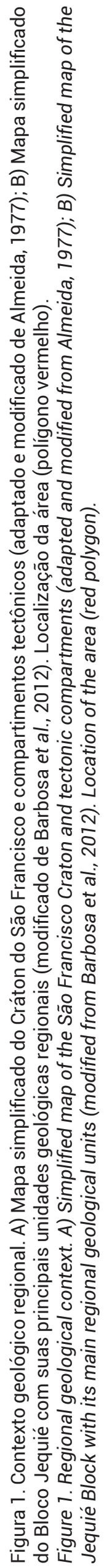


limites de detecção para a maioria dos elementos maiores ficaram na ordem de $0,01 \%$, enquanto os de elementos traço em 0,1 ppm.

Para estudos de química mineral, foram confeccionadas 11 lâminas polidas. As análises foram realizadas no Laboratório de Difração de Raios-X e Microssonda Eletrônica - LABSONDA, da Universidade Federal do Rio de Janeiro (UFRJ), onde se utilizou a microssonda do tipo Jeol JXA8230, com voltagens de aceleração de $15 \mathrm{kV}$ para silicatos e $20 \mathrm{kV}$ para opacos com corrente de 20 nA.

Osdadosquímicosforam tratadosutilizando diagramas elaborados no software MinPet 2.02 (Richard, 1995) e planilhas da Microsoft Excel. Para os dados de geotermobarometria foi utilizado o software PTMAFIC (Soto \& Soto, 1995) e planilha excel de Putirka (2008).

\section{Resultados}

\subsection{Geologia do corpo máfico-ultramáfico}

Morfologicamente, o corpo compreende terrenos com forte arrasamento topográfico com cotas variando entre $280 \mathrm{~m}$ e $300 \mathrm{~m}$ (Fig. 3A). Os peridotitos ocorrem, predominantemente, na porção sul (Fig. 2). Em campo, apresentam cor verde a cinza escuro, são caracterizados com granulação fina e forte susceptibilidade magnética. A serpentina alterou quase por completo a rocha dunítica, imprimindo coloração verde esmaecida (Fig. 3B e 3C). Na porção oeste são cartografados silexito magnético e lateritas concrecionais.

0 harzburgito (Figura 4D) apresenta cor cinza a verde escuro, com textura média a grossa. Possui textura porfirítica ocasionalmente, além de cumulática marcada por oicocristais de ortopiroxênio e presença de forte susceptibilidade magnética. Nos testemunhos de sondagem é possível observar essa característica, a qual é caracterizada por manchas esbranquiçadas de ortopiroxênio, em meio à serpentina de cor escura (Fig. 4D). O Iherzolito exibe granulação relativamente menor e a serpentina ocorre de forma subordinada (Fig. 4G).

Os piroxenitos ocorrem entre as porções noroeste, central e nordeste da

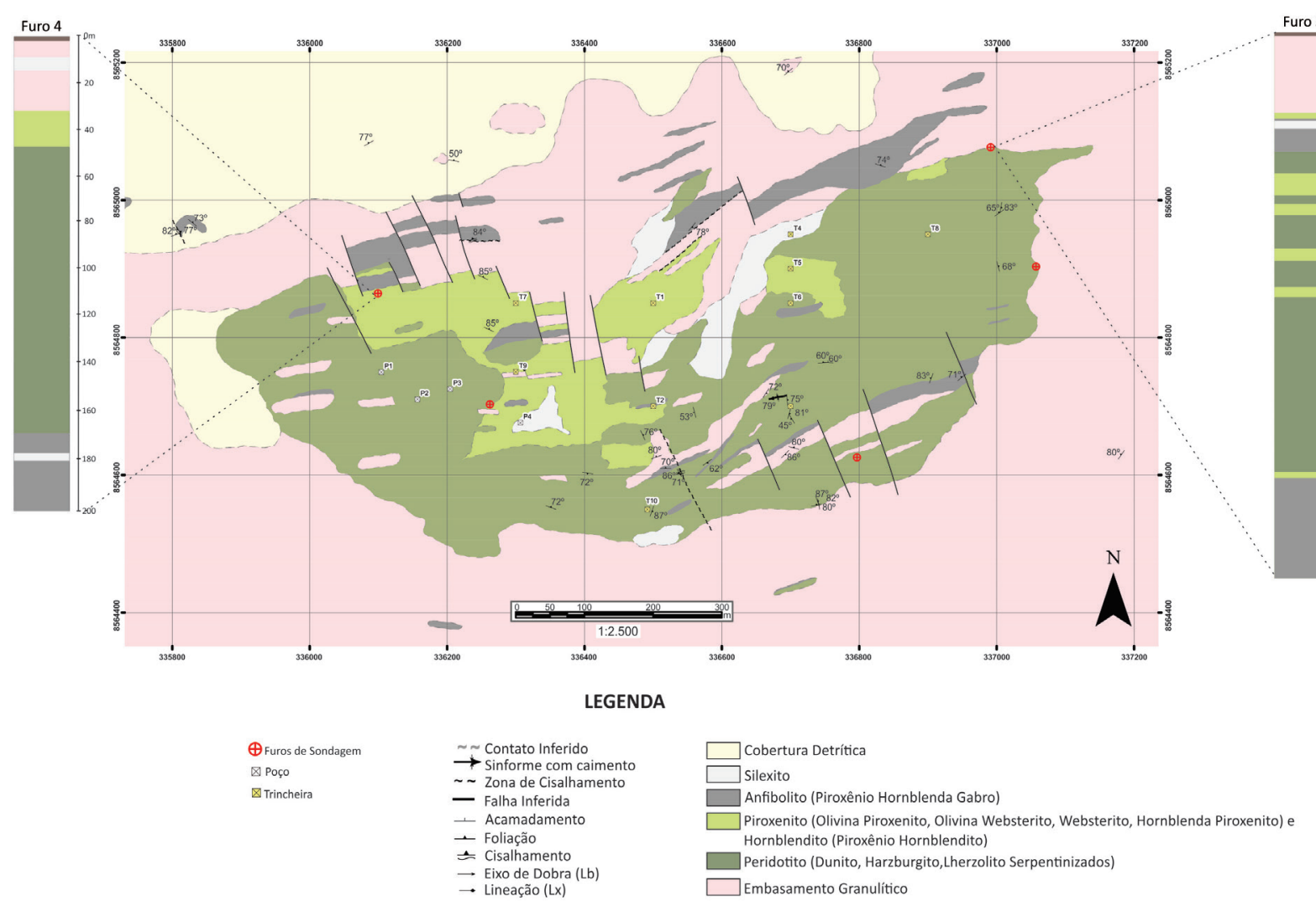

Figura 2. Mapa geológico local e coluna estratigráfica dos testemunhos de sondagem 4 e 5 representando as unidades. Figure 2. Local geological map and stratigraphic column of the core drill 4 and 5 representing the units. 


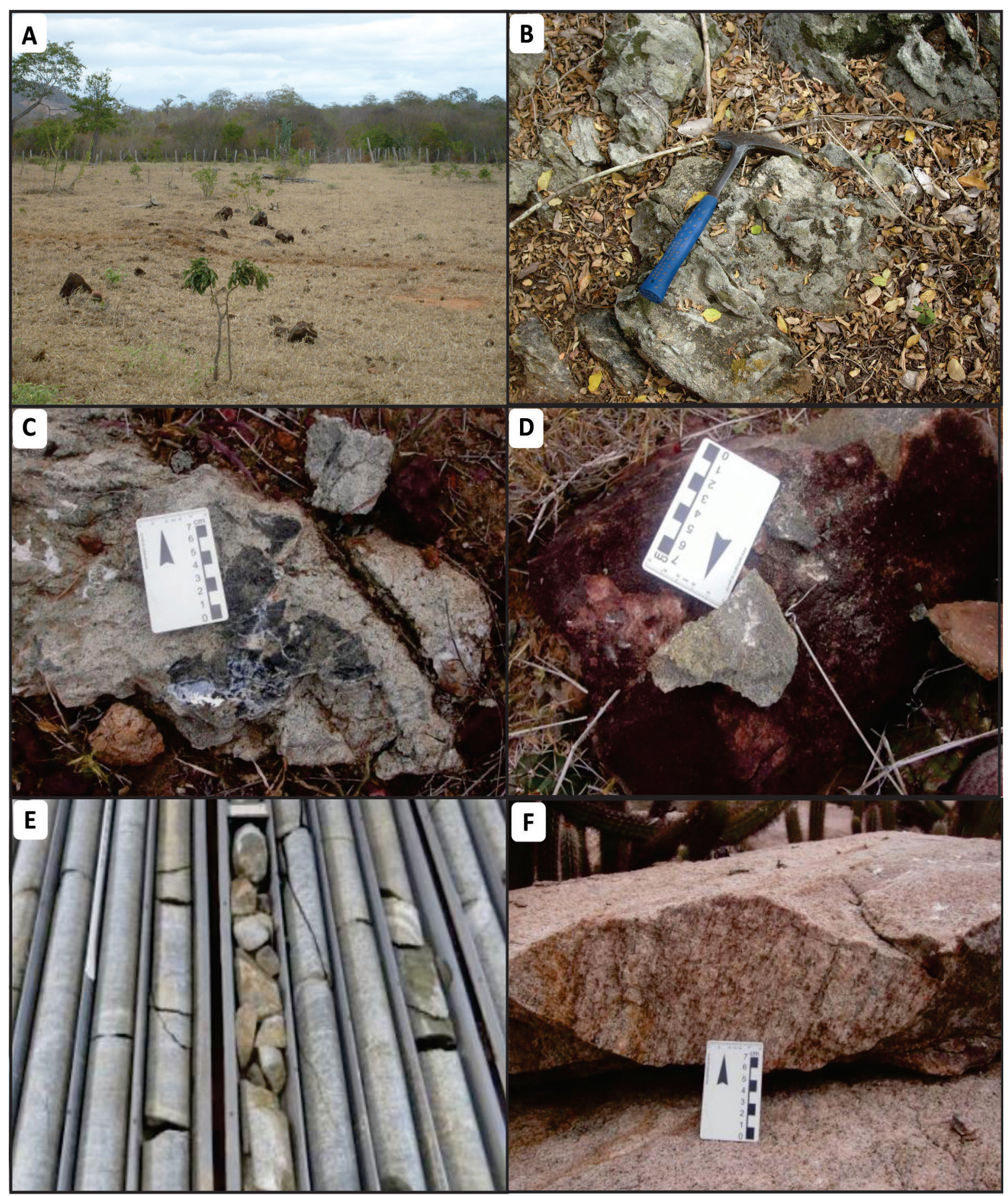

Figura 3. Características macroscópicas (observações de afloramento e testemunho de sondagem) das rochas. A) Remanescentes do corpo máfico-ultramáfico aflorando em terreno arrasado topograficamente; $B, C)$ Rocha peridotítica com formação de serpentina e presença de silexito; D) Rocha piroxenítica com alteração intempérica; E) Anfibolito em testemunho de sondagem; F) Afloramento, em detalhe, da encaixante granulítica.

Figure 3. Macroscopic (outcrop and core drill observations) features of the rocks. A) Outcrop with remnants of the mafic-ultramafic body; B, C) Peridotitic rock with serpentine formation and presence of silexite; D) Pyroxenitic rock with weathering alteration; E) Amphibolite in the core drill; F) Outcrop, in detail, of the granulitic insert. 
área, desenvolvendo, por vezes, contatos intergiditados e/ou abruptos com as outras unidades, devido, principalmente, a falhamentos NW-SE. Ocorrem na estratigrafia de forma subordinada, as rochas que compõem esta unidade apresentam cor variando entre cinza e verde escuro, são holomelanocrática, possuindo coloração marrom a preta (Fig. 5D). A textura é fina a grossa com aspecto, comumente, sacaroidal e de baixa susceptibilidade magnética. Em testemunhos, é observada, em alguns locais, orientação preferencial dos minerais (Fig. 5D, $\mathrm{G}$ ). Às vezes, os litotipos se mostram bastante fraturados com presença de carbonatos entre as fraturas.

O anfibolito, de protólito máfico (Fig. 3E), corresponde ao representante litológico mais diferenciado do corpo, estando, frequentemente, associado à zona de contato com embasamento granulítico na porção norte e sul da área mapeada e, por vezes, deslocado por movimentação estrutural. Macroscopicamente, exibe cor cinza escura, é mesocrático, apresenta granulação fına a grossa, além de baixa susceptibilidade magnética.

A encaixante do corpo máfico-ultramáfico ocorre sob a forma de lajedo formando solos de cor ocre e textura areno-argilosa. A rocha apresenta cor cinza a rosa, granulação média a grossa formada por minerais de feldspato e quartzo predominantemente (Fig. 3F). Não há presença de magnetismo nesse litotipo, o mesmo apresenta foliação penetrativa N025․ Os contatos com o corpo, geralmente, são estruturais, porém, também são observados contatos por assimilação.

\subsection{Petrografia do corpo máfico-ultramáfico}

Petrograficamente, oito litotipos foram classificados por estimativa visual. A tabela 1 exibe a composição mineralógica modal, em porcentagem, dos minerais que compõem o corpo.

\subsubsection{Litotipos ultramáficos}

As rochas ultramáficas foram caracterizadas em três unidades principais: peridotitos, piroxenitos e hornblendito. A partir da composição modal, as rochas peridotíticas foram classificadas como: dunito, harzburgito e Iherzolito, as piroxeníticas como: olivina ortopiroxenito, olivina websterito, websterito e hornblenda piroxenito e, por fim, o hornblendito, classificado como piroxênio hornblendito.

\subsubsection{Peridotitos}

Os peridotitos predominam na estratigrafia do corpo, as rochas que formam esta unidade ocorrem, no geral, intercaladas em bandas métricas com preponderância de harzburgito e dunito. São inequigranulares, marcados por fenocristais de ortopiroxênio, a equigranulares, sobretudo, no dunito. A presença de serpentina é mais expressiva à medida que a quantidade de olivina aumenta na composição modal, chegando a formar serpentinito a partir do dunito. Ocorrem vênulas de carbonato e magnetita, esta última, principalmente, associada à serpentina nessas rochas. Por vezes, as rochas exibem uma direção preferencial, marcada pelos fenocristais de ortopiroxênio.

No dunito, o qual está bastante serpentinizado (Fig. 4C), é possível observar textura mesh com pseudomorfos de olivina serpentinizada (Fig. 4B), textura mesocumulática 7-25\% de intercúmulus, conforme Wager et al. (1960), marcada por opacos pós-cumuláticos, entre os pseudomorfos de olivina (Fig. 4B) e alguns relictos de oicocristais de ortopiroxênio. Nessa rochas é verificada clorita de forma subordinada.

No harzburgito, a serpentina ocorre, principalmente, nos locais onde havia olivina (Fig. $4 \mathrm{D}, 4 \mathrm{E})$, mas também ocorre em ortopiroxênio formando bastita. Nessa rocha é possível observar fenocristais de ortopiroxênio (Fig. 4F) como oicocristais, apresentando olivina e espinélio cúmulus, assinalando uma textura mesocumulática a ortocumulática 25-50\% de cristais intercúmulus, segundo (Wager et al., 1960).

O Iherzolito, assim como o harzburgito, está, parcialmente, serpentinizado (Fig. 4H) e exibe texturas mesh, bastita, semelhantes ao dunito e harzburgito. É possível observar a presença 
Tabela 1. Composição modal por estimativa visual petrográfica e respectiva classificação das rochas. Abreviações: Ol: Olivina; Opx: Ortopiroxênio; Cpx: Clinopiroxênio; Amp: Anfibólio; PI: Plagioclásio; Spl: Espinélio; Srp: Serpentina; Opq: Opaco; Chl: Clorita; Ind: Indigsita; Tlc: Talco; Ttn: Titanita; Ep: Epidoto; Tr: Traço.

Table 1. Modal composition by petrographic visual estimation and respective rock classification. Abbreviations: Ol: Olivine; Opx: Orthopyroxene; Cpx: Clinopyroxene; Amp: Amphibole; Pl: Plagioclase; Spl: Spinel; Srp: Serpentine; Opq: Opaque; Chl: Chlorite; Ind: Inddigsite; Tlc: Talc; Ttn: Titanite; Ep: Epidote; Tr: Trace.

\begin{tabular}{|c|c|c|c|c|c|c|c|c|c|c|c|c|c|c|}
\hline LÂMINA & Ol & Opx & Cpx & Amp & PI & Spl & Srp & Opq & Chl & Ind & Tlc & Ttn & Ep & CLASSIFICAÇÃO \\
\hline CM01-01 & 2 & 1 & - & - & - & - & 81 & 11 & 5 & - & - & - & - & Serpentinito \\
\hline CM02-03 & - & - & - & - & - & - & 86 & 6 & - & 8 & - & - & - & Serpentinito \\
\hline CM03-01 & - & - & - & - & - & - & 83 & 9 & 8 & - & - & - & - & Serpentinito \\
\hline CM03-06 & - & - & - & - & - & - & 80 & 20 & - & - & - & - & - & Serpentinito \\
\hline CM03-07 & - & - & - & - & - & - & 83 & 17 & - & - & - & - & - & Serpentinito \\
\hline CM03-08 & - & 6 & - & - & - & - & 73 & 19 & 2 & - & - & - & - & Serpentinito \\
\hline CM03-13 & - & - & - & - & - & - & 87 & 13 & - & - & - & - & - & Serpentinito \\
\hline CM04-10 & - & 3 & 1 & 3 & - & - & 74 & 15 & 4 & - & - & - & - & Serpentinito \\
\hline CM04-12 & - & 1 & 3 & - & - & - & 75 & 18 & 3 & - & - & - & - & Serpentinito \\
\hline CM04-14 & - & - & 2 & - & - & - & 84 & 8 & 6 & - & - & - & - & Serpentinito \\
\hline CM04-15 & - & 1 & 1 & - & - & - & 80 & 14 & 4 & - & - & - & - & Serpentinito \\
\hline CM05-02 & - & - & - & - & - & - & 97 & 3 & - & - & - & - & - & Serpentinito \\
\hline CM05-04 & - & - & - & - & - & - & 96 & 4 & - & - & - & - & - & Serpentinito \\
\hline CM05-05 & - & - & - & - & - & - & 93 & 7 & - & - & - & - & - & Serpentinito \\
\hline CM05-06 & - & - & - & - & - & - & 96 & 4 & - & - & - & - & - & Serpentinito \\
\hline CM05-08 & - & - & - & - & - & - & 92 & 8 & - & - & - & - & - & Serpentinito \\
\hline CM05-09 & - & - & - & - & - & - & 93 & 7 & - & - & - & - & - & Serpentinito \\
\hline CM05-10 & - & - & - & - & - & - & 87 & 13 & - & - & - & - & - & Serpentinito \\
\hline CM02-04 & 52 & 30 & 3 & - & - & - & - & 5 & 10 & - & - & - & - & Harzburgito \\
\hline CM05-07 & 28 & 58 & - & - & - & - & 8 & 6 & - & - & - & - & - & Harzburgito \\
\hline CM05-12 & 57 & 36 & - & - & - & - & - & 7 & - & - & - & - & - & Harzburgito \\
\hline CM01-07 & 58 & 23 & 8 & - & - & - & - & 9 & 2 & $\operatorname{Tr}$ & - & - & - & Lherzolito \\
\hline CM01-08 & 48 & 30 & 7 & - & - & - & - & 15 & - & - & - & - & - & Lherzolito \\
\hline CM04-08 & 45 & 34 & 6 & - & - & - & - & 15 & - & - & - & - & - & Lherzolito \\
\hline CM04-16 & 60 & 21 & 5 & - & - & - & - & 11 & 3 & - & - & - & - & Lherzolito \\
\hline CM04-18 & 49 & 30 & 5 & - & - & - & - & 14 & 2 & - & - & - & - & Lherzolito \\
\hline CM04-19 & 47 & 32 & 5 & - & - & - & - & 14 & 2 & - & - & - & - & Lherzolito \\
\hline CM04-20 & 49 & 23 & 6 & - & - & - & - & 21 & 1 & - & - & - & - & Lherzolito \\
\hline CM03-12 & 16 & 76 & 3 & - & - & - & - & 5 & - & - & - & - & - & Ol-ortopiroxenito \\
\hline CM04-09 & 12 & 65 & 3 & - & - & - & - & 11 & 9 & - & - & - & - & Ol-ortopiroxenito \\
\hline CM04-03 & 16 & 65 & 14 & - & - & - & - & 5 & - & - & - & - & - & Ol-werbsterito \\
\hline CM04-05 & 16 & 71 & 5 & - & - & - & - & 7 & 1 & - & - & - & - & Ol-werbsterito \\
\hline CM04-21 & 16 & 66 & 10 & - & - & - & - & 8 & - & - & - & - & - & Ol-werbsterito \\
\hline СМ02-06 & - & 68 & 14 & 2 & - & - & - & 2 & 14 & - & - & - & - & Websterito \\
\hline CM04-01 & 1 & 65 & 12 & - & - & - & - & 16 & 6 & - & - & - & - & Websterito \\
\hline CM04-04 & - & 64 & 31 & - & - & - & - & 3 & - & - & 2 & - & - & Hbl-piroxenito \\
\hline CM04-11 & 12 & 65 & 4 & 15 & - & - & - & - & 4 & - & - & - & - & Hbl-piroxenito \\
\hline CM01-03 & - & 42 & - & 52 & - & - & - & 6 & - & - & - & - & - & Px-hornblendito \\
\hline CM01-04 & - & 30 & - & 70 & - & - & - & - & - & - & - & - & - & Px-hornblendito \\
\hline CM01-06 & - & 14 & 6 & 70 & - & - & - & 2 & 6 & - & - & - & 2 & Px-hornblendito \\
\hline CM01-02 & - & - & 14 & 67 & 18 & - & - & - & - & - & - & - & - & Anfibolito \\
\hline CM02-02 & - & - & 6 & 62 & 32 & - & - & - & - & - & - & - & - & Anfibolito \\
\hline CM04-22 & - & - & 17 & 33 & 49 & - & - & - & - & - & - & 1 & - & Anfibolito \\
\hline CM04-23 & - & - & 7 & 40 & 53 & - & - & - & - & - & - & - & - & Anfibolito \\
\hline CM05-14 & - & - & 21 & 26 & 53 & - & - & - & - & - & - & - & - & Anfibolito \\
\hline
\end{tabular}




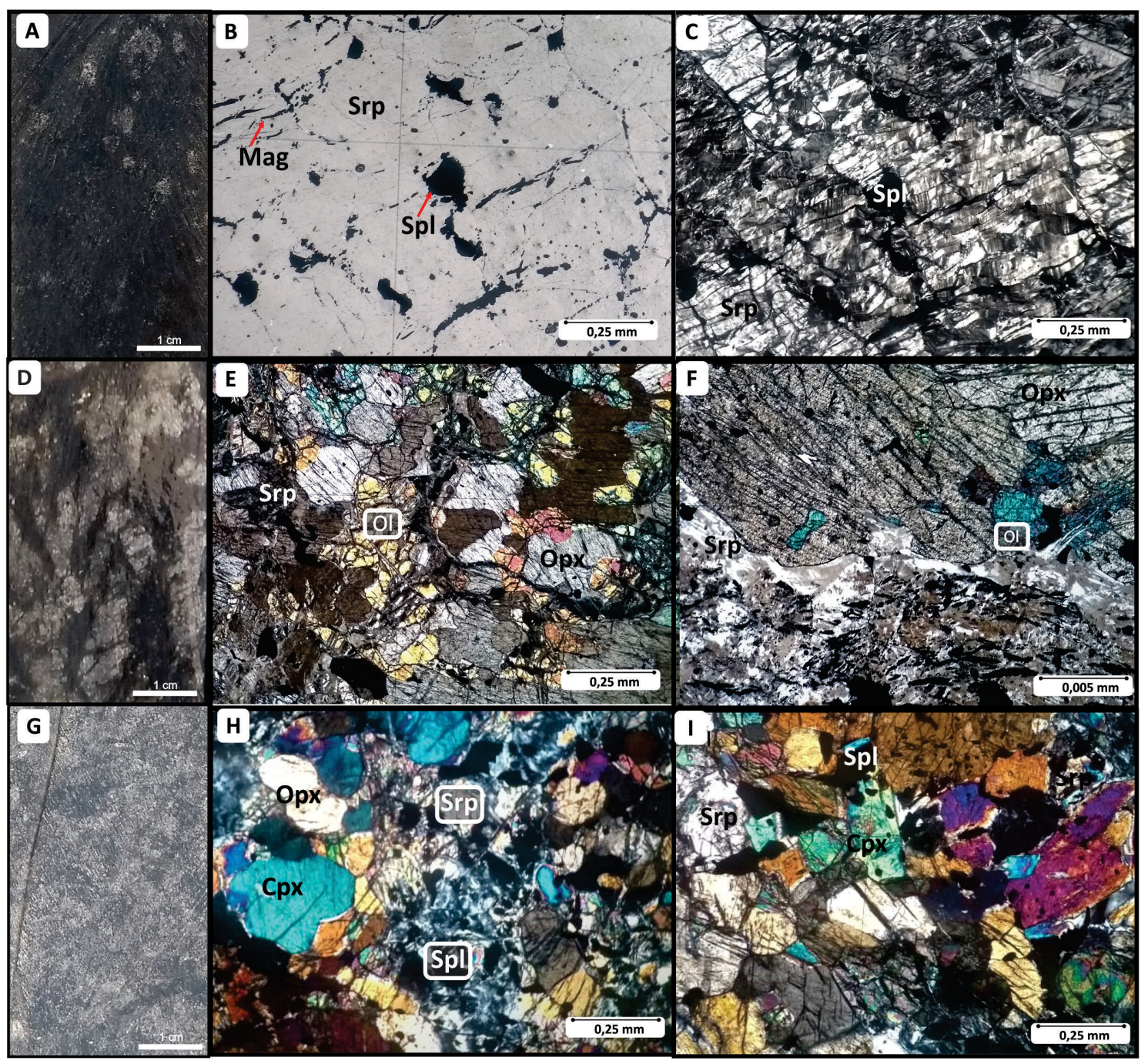

Figura 4. Feições dos peridotitos. A) Aspecto geral do dunito serpentinizado com relictos de ortopiroxênio; B, C) Pseudomorfos de olivina em textura mesocumulática; D) Aspecto do harzburgito com fenocristais de ortopiroxênio (porção branca) e serpentina (porção preta); E) Olivina e ortopiroxênio em textura ortocumlática; F) Oicocristal de ortopiroxênio com olivina e espinélio cumulatos; G) Aparência geral do Iherzolito com serpentina subordinada; H, I) Lherzolito parcialmente serpentinizado. Fotomicrografia A em nicóis descruzados. Fotomicrografias B, C, D, E, F em nicóis cruzados. Abreviações: Srp: Serpentina; Spl: Espinélio; Mag: Magnetita; Ol: Olivina; Opx: Ortopiroxênio; Cpx: Clinopiroxênio.

Figure 4. Features of the peridotites. A) General appearance of the serpentinized dunite with orthopyroxene relicts; $B, C$ ) Olivine pseudomorphs in mesocumulatic texture; D) Harzburgite aspect with orthopyroxene phenocrystals (white portion) and serpentine (black portion); E) Olivine and orthopyroxene in orthocumlatic texture; F) Orthopyroxene oikocrystals with cumulates olivine and spinel; $G$ ) General appearance of Iherzolite with subordinate serpentine; $H$, I) Partially serpentinized Iherzolite. Photomicrograph A in uncrossed nicols. Photomicrographs $C, E, F, H$, I in crossed nicols. Abbreviations: Srp: Serpentine; Spl: Spinel; Mag: Magnetite; Ol: Olivine; Opx: Orthopyroxene; Cpx: Clinopyroxene.

discreta de clinopiroxênio, assim como uma trama inequigranular e textura mesocumulática (Fig. 4H, 4I) com piroxênio e olivina cúmulos e opacos pós-cumuláticos. Observa-se, ainda, um mineral com características petrográficas similares às da antofilita. Nessas rochas, além da serpentina, ocorre talco, de forma subordinada, como pseudomorfo de ortopiroxênio.

A serpentina (8-97\%) é incolor e exibe hábito granular poligonal a fibroso/asbestiforme com a forma variando entre idioblástica a xenoblástica, respectivamente. A magnetita sempre ocorre associada à serpentina, nas zonas de fraqueza da olivina, entre os seus contatos e/ou entre as clivagens do ortopiroxênio.

A olivina (2-60\%), quando preservada, é incolor, exibe hábito granular e forma anédrica. Ocorre tanto na trama mineral como cúmulus no ortopiroxênio, formando textura poiquilítica. Apresenta em sua estrutura fraturas que são aproveitadas por serpentina com magnetita associada. 
O ortopiroxênio (1-58\%) é caracterizado como fenocristais, ocorrendo como oicocristais com até $1 \mathrm{~cm}$ de comprimento, englobando espinélio e olivina. É incolor a rosa pálido, varia entre pseudomorfo serpentinizado a relativamente preservado, em bastita. Exibe hábito tabular com borda interlobada, principalmente nos fenocristais. Em sua clivagem ocorre formação de clorita, além de serpentina e talco. Observam-se raras exsoluções de fases mais férricas, além de exsoluções de possível clinopiroxênio.

O clinopiroxênio (1-8\%) exibe hábito tabular prismático e forma subédrica a anédrica, em meio à trama ígnea.

O espinélio (6-21\%) exibe cor verde escuro, hábito prismático e tem forma anédrica. Está incluso nos cristais de ortopiroxênio e, subordinadamente, entre os contatos dos demais minerais. Nessas rochas ocorrem minerais acessórios como: magnetita secundária e clorita, além de talco.

Ambos, espinélio emagnetita, ocorrem tanto como mineral intercumulático como cumulático, inclusos em ortopiroxênio. A magnetita ocorre, predominantemente, entre as fraturas da olivina e nas clivagens da ortopiroxênio, como mineral secundário.

\subsubsection{Piroxenitos}

Petrograficamente, no geral, os piroxenitos são equigranulares a inequigranulares com granulação média. A presença de serpentina, nesta unidade é relativamente incipiente.

o olivina ortopiroxenito exibe trama equigranular a inequigranular. É formado por fenocristais de ortopiroxênio, ocorrendo como oicocristais com olivina e espinélio inclusos e com serpentina em suas clivagens. A maioria dos opacos é secundária, ocorrendo associada à serpentina, é possível observar também clorita em meio à serpentina (Fig. 5B).

O olivina websterito exibe granulação mais fina comparada ao olivina ortopiroxenito. Apresenta olivina ocorrendo entre os cristais de ortopiroxênio (Fig. 5C), este último, mais preservado marca a mudança de mineral cúmulus do corpo. O websterito é caracterizado por grandes cristais de ortopiroxênio e, subordinadamente, clinopiroxênio e, apresenta textura adcumulática $(0-7 \%$ de minerais intercúmulus, Wager et al., 1960).

Foram caracterizadas unidades com hornblenda como mineral essencial, no hornblenda piroxenito e também no piroxênio hornblendito. O hornblenda piroxenito é inequigranular, marcado por alguns fenocristais de ortopiroxênio. A rocha é adcumulática de cristais de piroxênio que se tocam, entretanto, é possível observar em outros locais que a hornblenda ocorre entre os cristais de piroxênio e dentro dos mesmos (Fig. 5E), aparentando ser produto destes por processo de uralitização. Alguns cristais de ortopiroxênio apresentam microestrutura do tipo kink band (Fig. 5F).

No piroxênio hornblendito, é possível observar discreta orientação preferencial dos minerais da trama, marcada, sobretudo, pela hornblenda. A hornblenda está mais desenvolvida que no hornblenda piroxenito e ocorre englobando os minerais de ortopiroxênio (Fig. 5H, 5I). A rocha é adcumulática com alguns opacos entre os contatos dos minerais de trama (pós-cúmulus).

O ortopiroxênio (14-76\%) ocorre como oicocristais pós-cumuláticos no olivina ortopiroxenito com hábito tabular, borda interlobada e forma subédrica. No olivina websterito, os cristais apresentam-se com tamanho menor, hábito prismático a granular e borda reta. Nesses cristais menores, a presença de serpentina é rara. No piroxênio hornblendito ocorre, principalmente, como cristais relictos englobados pela hornblenda. Nas suas clivagens é possível observar exsolução de augita.

A olivina (1-16\%) é incolor, exibe hábito granular e forma anédrica, ocorre como pequenos cristais entre os cristais de piroxênio no olivina websterito. O clinopiroxênio (3-31\%) apresenta cor verde pálido, hábito prismático e forma subédrica a anédrica.

A hornblenda (2-70\%) exibe pleocroísmo verde pálido a verde, apresenta forma anédrica em hornblenda piroxenito, hábito prismático e forma euédrica a subédrica em piroxênio hornblendito. A hornblenda ocorre, parcialmente, entre o ortopiroxênio da trama cumulática e, quando bem desenvolvida, é a fase principal 


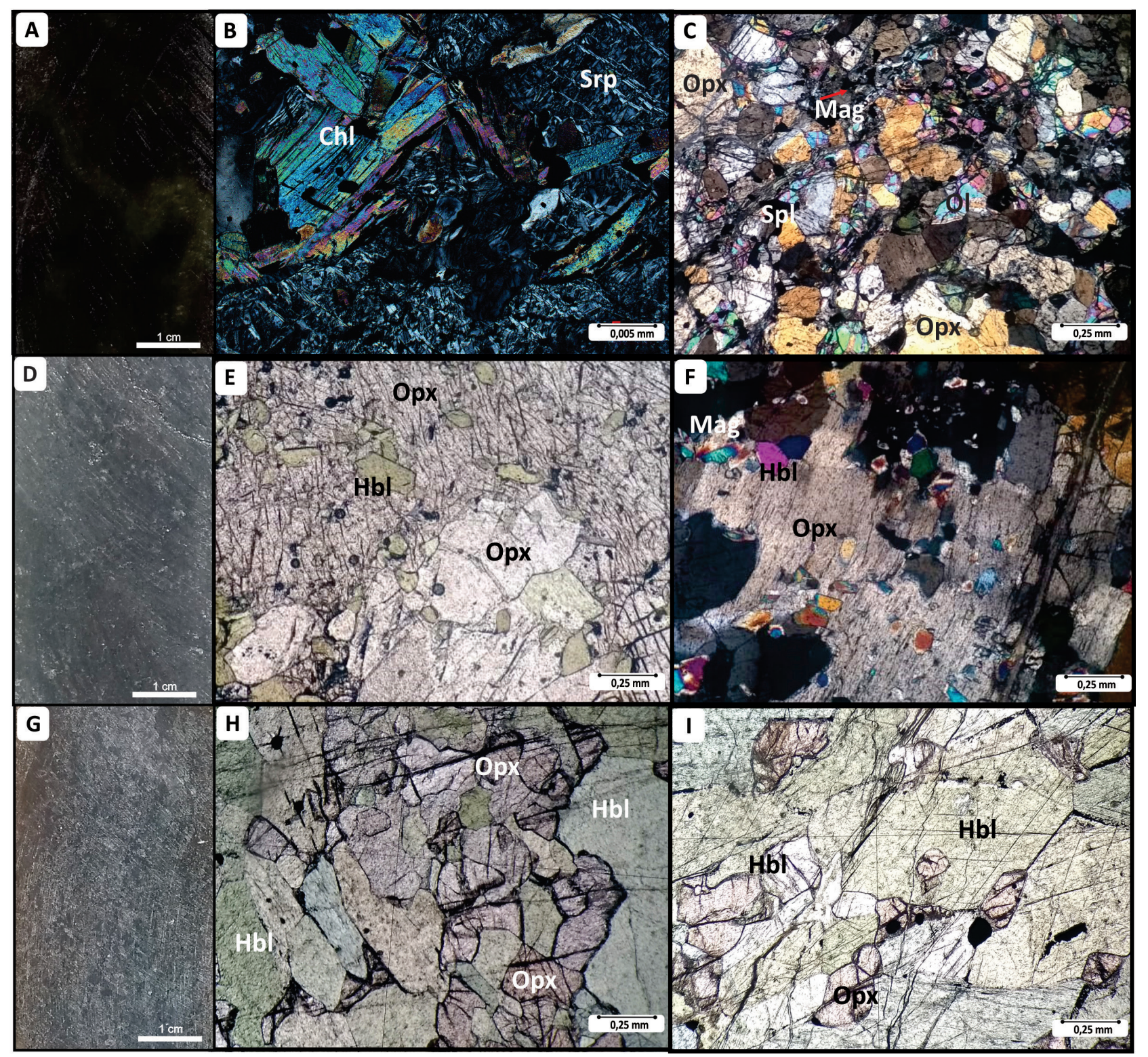

Figura 5. Feições de peridotitos e piroxenitos. A) Rocha dunítica serpentinizada; B) Clorita formada a partir da serpentina; C) Olivina ocorrendo entre os cristais de ortopiroxênio; D) Aspecto geral macroscópico do hornblenda piroxenito; E) Hornblenda entra as bordas e clivagens do ortopiroxênio; F) Extinção ondulante em ortopiroxênio com microestrutura kink band; G) Aspecto geral macroscópico do piroxênio hornblendito; H) Hornblenda formando a partir do ortopiroxênio; I) Relicto de ortopiroxênio na hornblenda. Fotomicrografias B, C, F em nicóis cruzados. Fotomicrografias E, H, I em nicóis descruzados Abreviações: Chl: Clorita; Srp: Serpentina; Opx: Ortopiroxênio; Mag: Magnetita; Spl: Espinélio; Ol: Olivina; Hbl: Hornblenda.

Figure 5. Features of the peridotites and pyroxenites. A) Serpentinized dunitic rock; B) Chlorite formed from the serpentine; C) Olivine occurring between orthopyroxene crystals; D) Macroscopic appearance of the hornblende pyroxenite; E) Hornblende between at the edges and cleavages of orthopyroxene; F) Undulose extinction in orthopyroxene with kink band microstructure; G) Macroscopic appearance of the pyroxene hornblendite; $H$ ) Hornblende forming from orthopyroxene; I) Relict orthopyroxene between in hornblende structure. Photomicrographs B, C, F in crossed nicols. Photomicrographs E, H, I in uncrossed nicols. Abbreviations: Chl: Chlorite; Srp: Serpentine; Opx: Orthopyroxene; Mag: Magnetite; Spl: Spinel; Ol: Olivine; Hbl: Hornblende. 
no piroxênio hornblendito. A clorita (1-14\%) apresenta hábito lamelar, forma subdioblástica, alcançando tamanho de 0,2 mm, ocorre no olivina ortopiroxenito, sendo formada a partir da serpentina e ortopiroxênio.

\subsubsection{Anfibolito}

A porção máfica exibe composição, relativamente, monótona e foi metamorfizada formando anfibolito. A partir de sua composição foi possível classificá-la como piroxênio hornblenda gabro.

O anfibolito ocorre, predominantemente, em profundidade nos testemunhos de sondagem (Fig. 7A, 8). A rocha é equigranular a inequigranular e exibe orientação preferencial em toda a trama mineralógica. É possível observar textura nematoblástica (Fig. 7D, 7E) marcada pela orientação da hornblenda e plagioclásio. Além da recristalização metamórfica, nota-se reação marcada pela quebra da hornblenda (Fig. 7C, 7D) e formação do diopsídio + plagioclásio (Bucher \& Grapes, 2011).

A hornblenda (26-67\%) exibe hábito prismático com borda reta a interlobada, forma subdioblástica a xenoblástica. 0 plagioclásio (18-53\%) apresenta hábito tabular e forma subdiomórfica, raramente exibe maclas polissintéticas, apresenta em sua estrutura saussurita e sericita subordinada. 0 diopsídio (6-21\%) apresenta hábito prismático e forma xenoblástica. Esse litotipo exibe um microbandamento composicional.

\subsection{Química mineral}

Seis fases minerais foram analisadas por microssonda eletrônica, sendo descritas a seguir: olivina, piroxênio, anfibólio, plagioclásio, clorita e opacos.

\subsubsection{Olivina}

Foram realizadas 34 análises químicas na olivina do dunito, harzburgito, Iherzolito, olivina ortopiroxenito e olivina websterito (Tab. 1 do material suplementar), possibilitando verificar ausência de diferença composicional significativa. De forma geral, os teores de forsterita variam de $\mathrm{FO}_{85}$ a $\mathrm{Fo}_{92}$, classificando a olivina entre forsterita e crisólita para as rochas peridotíticas e piroxeníticas (Fig. 9). Para o dunito, os teores de forsterita variam entre $\mathrm{Fo}_{87}$ a $\mathrm{Fo}_{88^{\prime}}$ para o harzburgito de $\mathrm{Fo}_{88}$ a $\mathrm{Fo}_{92}$ e para o Iherzolito entre $\mathrm{Fo}_{85}$ a $\mathrm{Fo}_{90}$. No olivina ortopiroxenito, os teores variam $\mathrm{Fo}_{81}$ a $\mathrm{Fo}_{87}$ e, por fim, para o olivina websterito, variam entre $\mathrm{Fo}_{88}$ a $\mathrm{Fo}_{89}$.

\subsubsection{Piroxênio}

Foram realizadas 72 análises em ortopiroxênio e clinopiroxênio nos litotipos ultramáficos e anfibolito (Tab. 2 do material suplementar). Os minerais analisados plotam na área Quad (piroxênios de Fe-Mg-Ca; Morimoto, 1990), sendo classificados pelo diagrama En - Fs - Wo (Fig. 10). Para o ortopiroxênio, o teor de enstatita varia de $\mathrm{En}_{93}$ no dunito a $\mathrm{En}_{69}$ no harzburgito, sendo que este último teor caracteriza a composição de exsolução. Nos piroxenitos, varia de $\mathrm{En}_{87}$ para o olivina websterito a $E n_{80}$ no websterito. O clinopiroxênio apresenta $\mathrm{En}_{60}$ no Iherzolito a $E n_{58}$ no olivina ortopiroxenito. Os valores de $\mathrm{Al}_{2} \mathrm{O}_{3}$ variam em alguns piroxênios, apresentando valor mínimo de 0,46 e máximo de $27,25 \%$. Os piroxênios foram classificados como enstatita e augita nos litotipos ultramáficos. No anfibolito, o clinopiroxênio foi classificado como diopsídio.

\subsubsection{Plagioclásio}

Foram realizadas 14 análises em plagioclásio, o qual foi reequilibrado em fácies anfibolito, (Tab. 3 do material suplementar). De maneira geral, foi observado um zoneamento composicional discreto entre núcleo e borda, mas somente no teor de An, não ocorrendo variação entre plagioclásios. O plagioclásio apresentou teor de anortita variando entre $A n_{56}$ a $A n_{70}$, plotando no campo da labradorita (Fig. 11).

\subsubsection{Anfibólio}

Foram feitas 23 determinações analíticas no anfibólio de natureza ígnea no horblenda piroxenito e de natureza metamórfica no anfibolito 
A

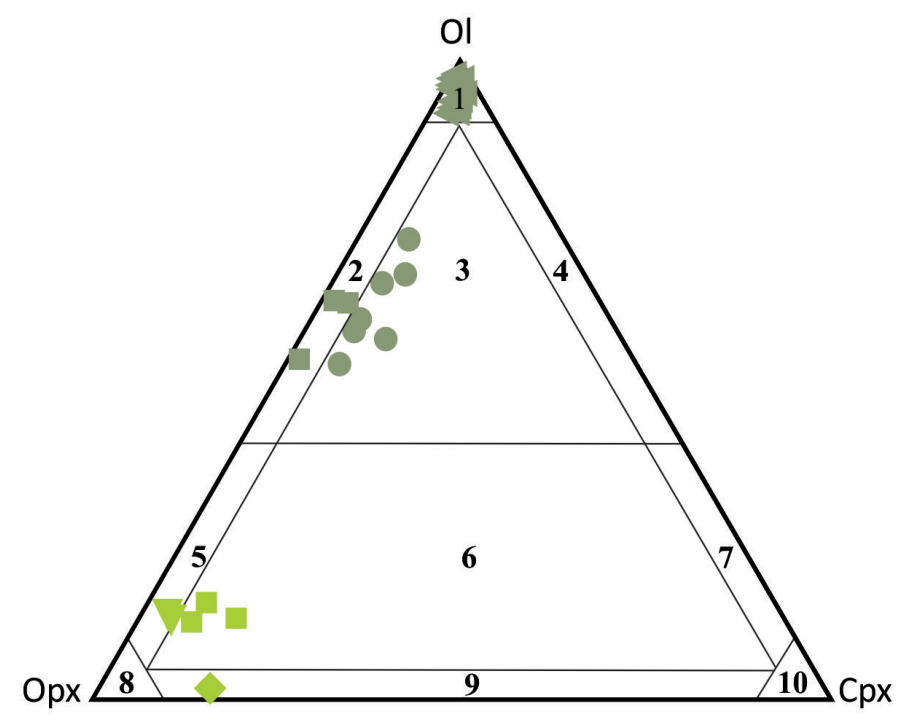

\title{
LEGENDA
}

Litotipos Ultramáficos

1-Dunito

2-Harzbugito

3-Lherzolito

4-Wehrlito

5-Olivina Ortopiroxenito

6-Olivina Websterito

7-Olivina Clinopiroxenito

8-Ortopiroxenito

9-Websterito

10-Clinopiroxenito

\author{
4 Dunito \\ - Harzburgito \\ - Lherzolito \\ $\checkmark$ Olivina Ortopiroxenito \\ Olivina Websterito
}

B

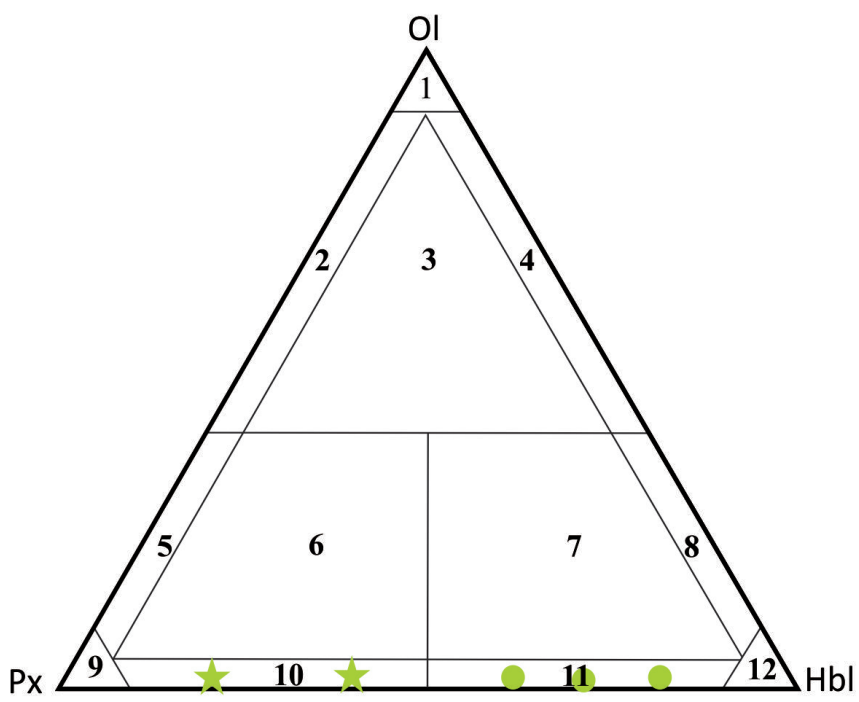

Litotipos Ultramáficos c/ Hornblenda

1-Dunito

2-Piroxênio Peridotito

3-Piroxênio Hornblenda Peridotito

4-Hornblenda Peridotito

5-Olivina Piroxenito

6-Olivina Hornblenda Piroxenito

7-Olivina Piroxênio Hornblendito

8-Olivina Hornblendito

9-Piroxenito

10-Hornblenda Piroxenito

11-Piroxênio Hornblendito

12-Hornblendito

Figura 6. Diagrama modal de classificação. A) Ol - Opx - Cpx; B) Ol - (Orto \pm Cpx) - Hbl (Streckeisen, 1976) para a unidade ultramáfica da área de estudo.

Figure 6. Modal classification diagram. A) Ol - Opx - Cpx; B) Ol - (Orto \pm Cpx) - Hbl (Streicksen, 1976) for the ultramafic unit of the study area. 


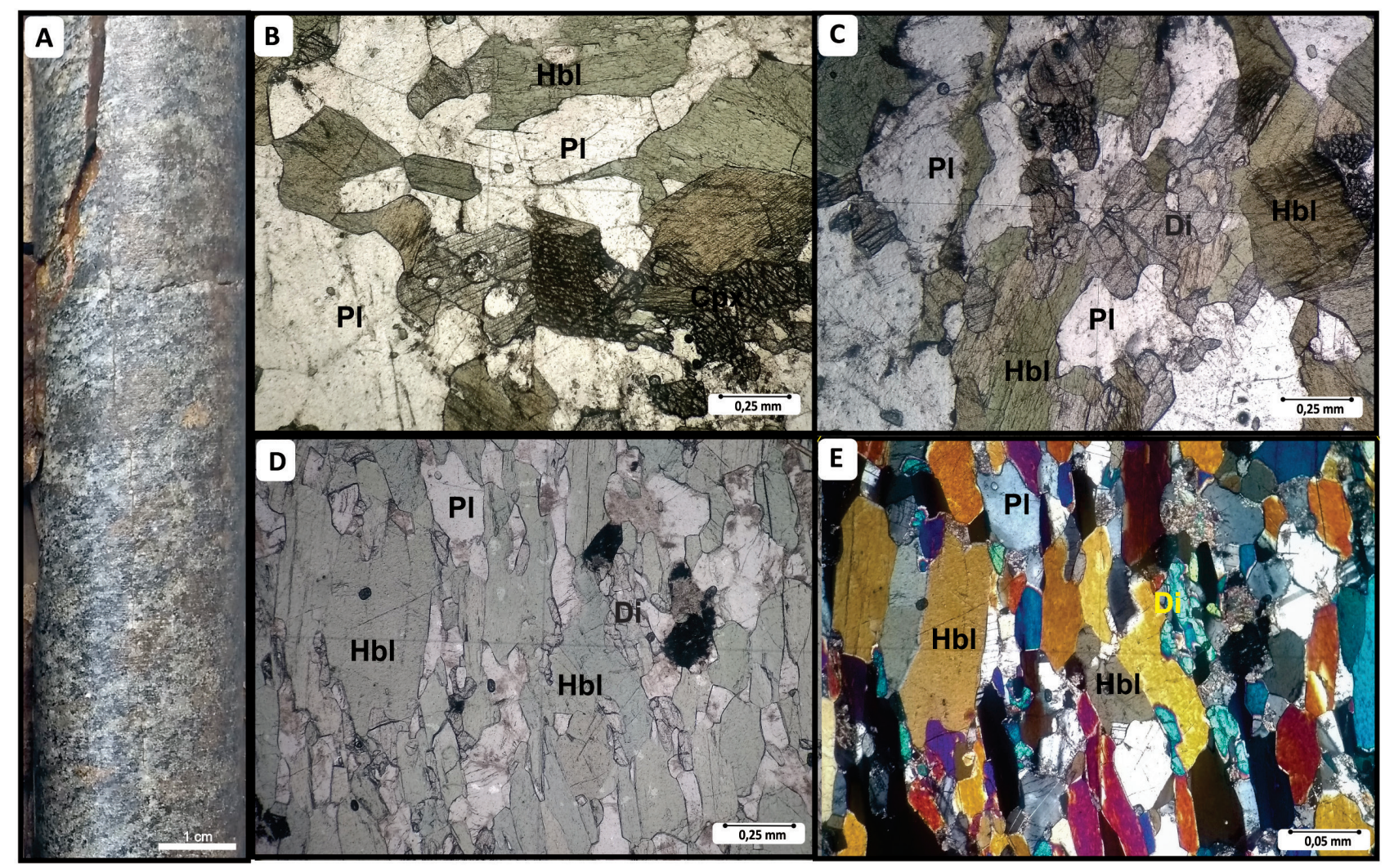

Figura 7. Feições do anfibolito. A) Anfibolito em testemunho de sondagem com foliação penetrativa; B, C, D, E) Aspecto geral do anfibolito com associação de labradorita + magnésio hornblenda + diopsídio; D, E) Textura nematoblástica, recristalização e formação do diopsídio. Fotomicrografias B, C, D em nicóis descruzados. Fotomicrografia E em nicóis cruzados. Abreviações: Pl: Labradorita; Hbl: Magnésio-hornblenda; Di: Diopsídio.

Figure 7. Features of the amphibolite. A) Amphibolite with penetrative foliation in core drill; B, C, D, E) General appearance of the amphibolite with plagioclase + magnesium hornblende + diopsídio association; $D, E)$ nematoblastic texture, recrystallization and diopside formation. Photomicrographs $B, C, D$ in uncrossed nicols. Photomicrograph $E$ in crossed nicols. Abbreviations: Pl: Plagioclase; Hbl: Magnesium-hornblende; Di: Diopside.

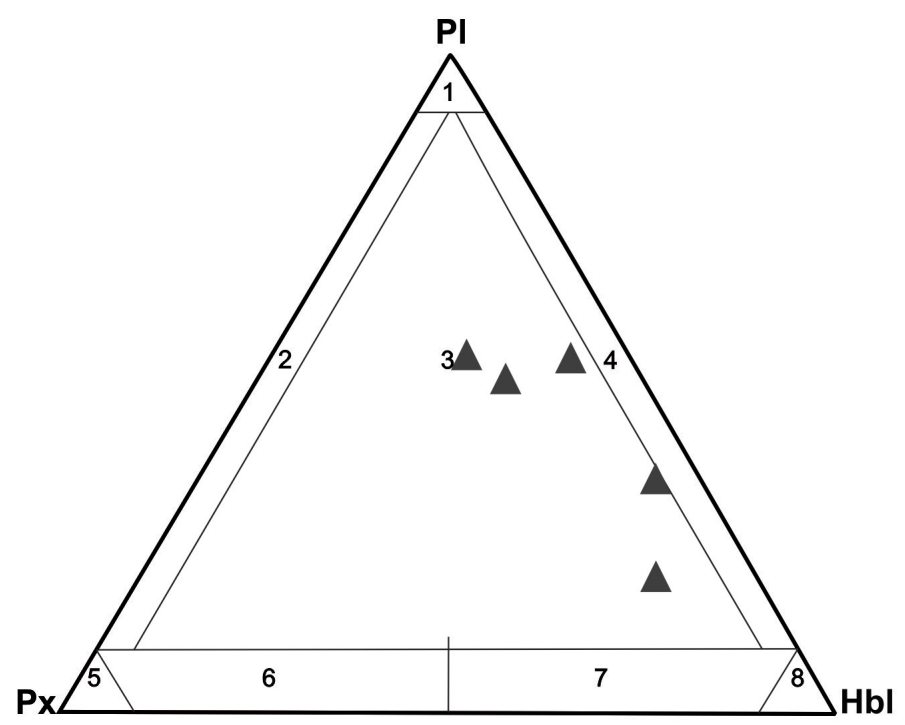

\section{LEGENDA}

\section{Anfibolito}

\section{Litotipos Máficos \\ 1-Anortosito \\ 2-Gabro/Gabronorito/Norito \\ 3-Piroxênio Hornblenda Gabronorito \\ Gabro/Gabronorito/Norito \\ 4-Hornblenda Gabro \\ 5-Piroxenito c/ Plagioclásio \\ 6-Piroxenito Hornblenda c/ Plagioclásio \\ 7-Hornblendito Piroxênio c/ Plagioclásio \\ 8-Hornblendito c/ Plagioclásio}

Figura 8. Diagrama modal de classificação PI - Px - Hbl modificado de Streckeisen (1976) e Le Maitre et al. (2002) para o anfibolito da área de estudo.

Figure 8. Pl - Px - Hbl modal classification diagram modified from Streckeisen (1976) and Le Maitre et al. (2002) for the amphibolite of the study area. 


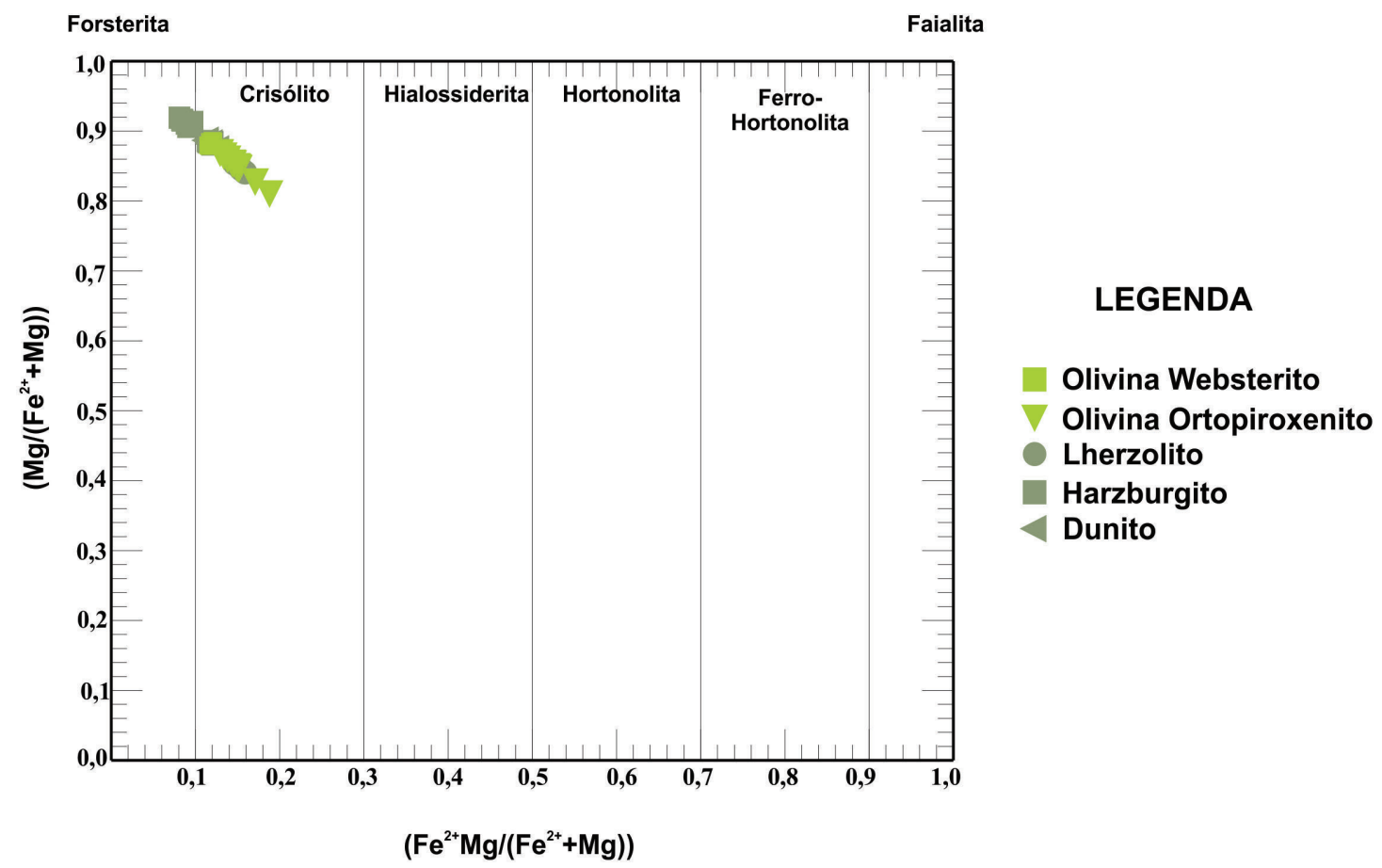

Figura 9. Diagrama de classificação da olivina, modificado de Deer et al. (1992). Figure 9. Olivine classification diagram, modified from Deer et al. (1992).

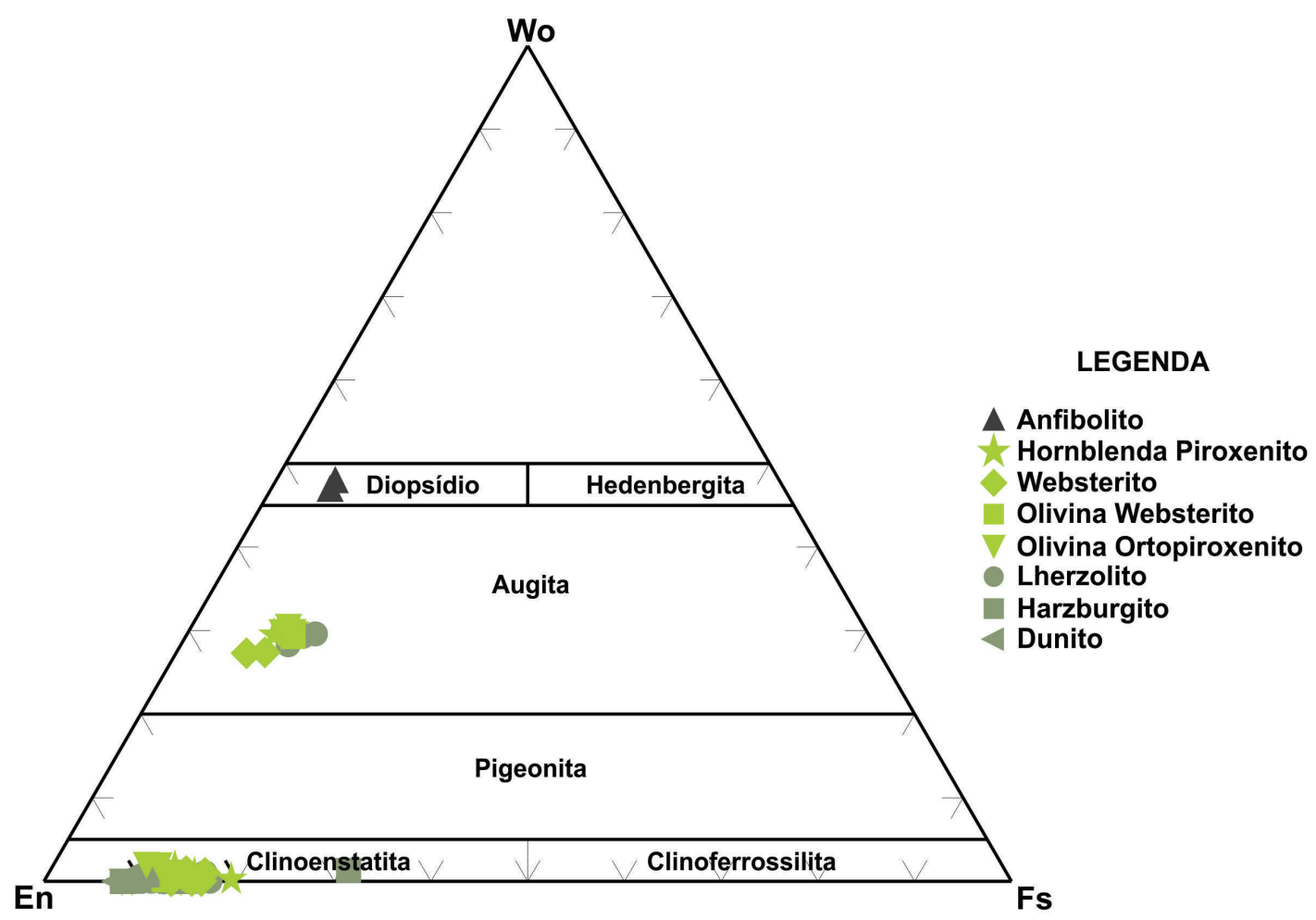

Figura 10. Diagrama de classificação dos piroxênios, modificado de Morimoto (1990). Figure 10. Pyroxenes classification diagram, modified from Morimoto (1990). 


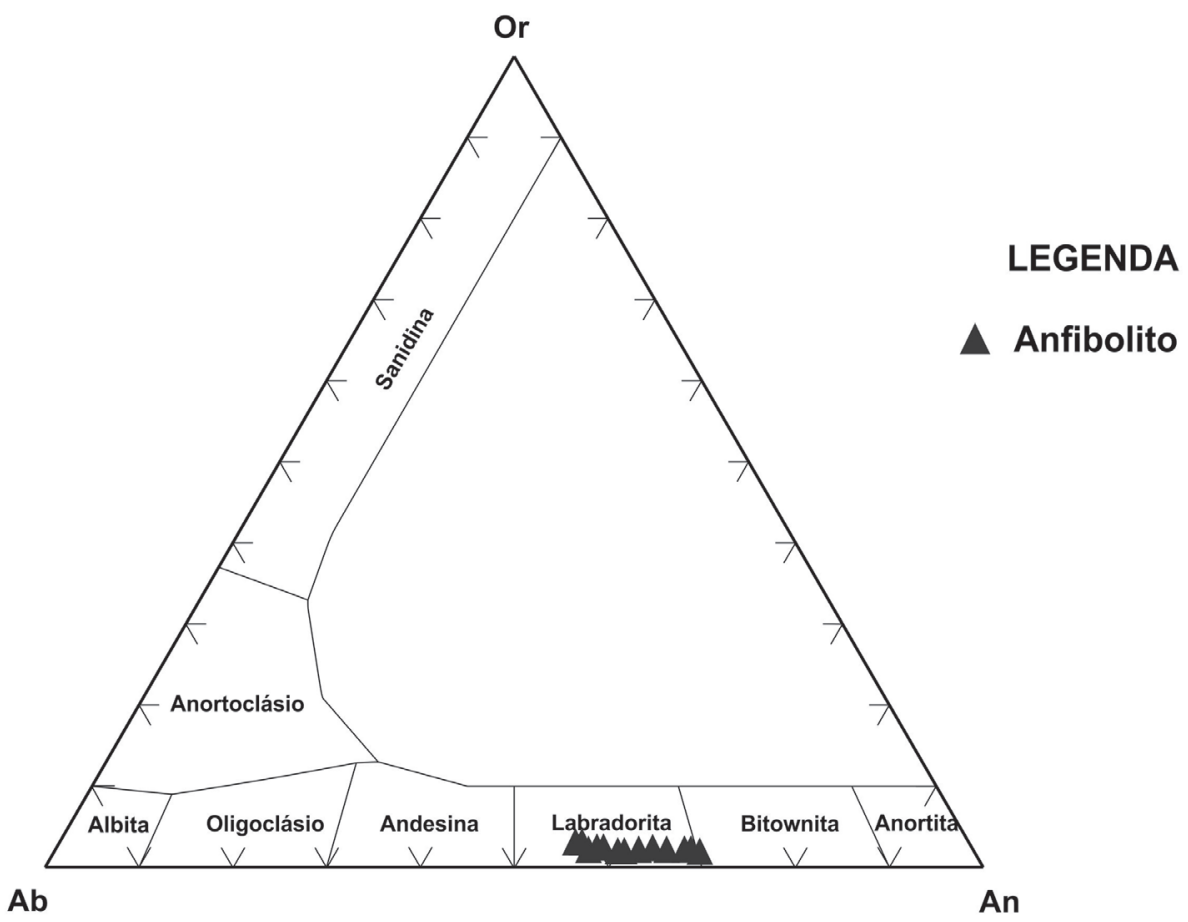

Figura 11. Diagrama de classificação do feldspato, segundo os componentes moleculares Ab-An-Or, modificado de Deer et al. (1992).

Figure 11. Feldspar classification diagram, according to the molecular components Ab-An-Or, modified from Deer et al. (1992).

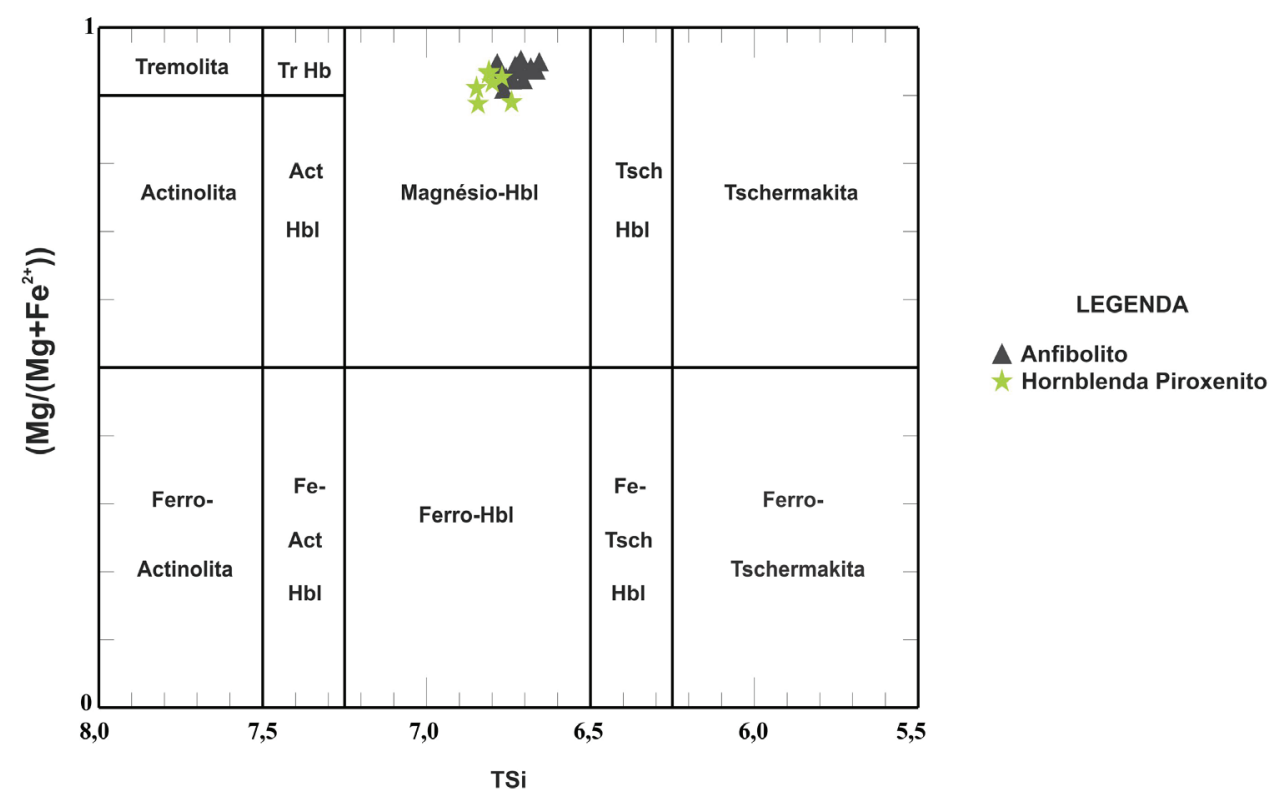

Figura 12. Diagrama de classificação do anfibólio, modificado de Leake et al. (1997). Abreviações: Tr Hbl: Tremolita hornblenda; Act Hbl: Actinolita hornblenda; Fe-Act Hbl: Ferro-actinolita hornblenda; Tsch Hbl: Tschermakita hornblenda; Fe-Tsch Hbl: Ferro-tschermakita hornblenda.

Figure 12. Amphibole classification diagram, modified from Leake et al. (1997). Abbreviation: Tr Hbl: Tremolite hornblende; Act Hbl: Actinolite hornblende; Fe-Act Hbl: Iron-actinolite hornblende; Tsch Hbl: Tschermakite hornblende; Fe-Tsch Hbl: Iron- tschermakite hornblende. 
(Tab. 4 do material suplementar). Conforme a classificação de Leake et al. (1997), o anfibólio de ambas as rochas está inserido na série cálcica, sendo classificado como magnésio-hornblenda (Fig. 12).

\subsubsection{Clorita}

Foram realizadas 6 análises de química mineral no dunito e harzburgito (Tab. 5 do material suplementar). Microscopicamente, a clorita é parecida, não sendo possível observar diferença, porém com a análise foi possível identificar dois tipos de clorita. A clorita associada à presença de serpentina caracterizada como talco-clorita e a clorita formada entre a clivagem da enstatita caracterizada como clinocloro (Fig. 13).

\subsubsection{Espinélio}

Os minerais opacos analisados nos peridotitos e piroxenitos representam as fases do grupo do espinélio (Tab. 6 do material suplementar), mais especificamente dos subgrupos do magnésio e ferro: espinélio (sensu stricto) e magnetita, respectivamente. Os valores das razões $\mathrm{Fe}^{2} /\left(\mathrm{Fe}^{2}+\mathrm{Fe}^{3}\right)$ e $\mathrm{Cr} /(\mathrm{Cr}+\mathrm{Al})$ variam entre rochas peridotíticas e entre as rochas piroxeníticas, não havendo aumento ou decrescimento progressivo.

\subsection{Geotermobarometria}

Com os dados de química mineral foram realizados cálculos termodinâmicos geotermométricos e geobarométricos em paragêneses minerais pré-determinadas com base em estudos empíricos. Para obter as temperaturas de cristalização e/ou reequilíbrio de paragêneses foi utilizado o geotermômetro clinopiroxênio - líquido (rocha total), neste caso, de Putirka (2008) (Tab. 2). Para os pares anfibólioplagioclásio foi utilizado o geotermômetro de Blundy \& Holland (1990) com base nas trocas catiônicas de NaSi-CaAl (Tab. 3).

Como demonstrado na tabela 2, para os geotermômetros de Putirka (2008), baseado na equação 33, a temperatura média foi de 1220,90 $\pm 23,83^{\circ} \mathrm{C}$ nas rochas ultramáficas. Na tabela 3 , o geotermômetro do par plagioclásio - anfibólio para o anfibolito apresentou temperatura média de $869,15 \pm 10,51^{\circ} \mathrm{C}$.

As condições de pressão metamórfica a que o corpo foi submetido foram calculadas a partir do geobarômetro de Hollister et al. (1987) que usa a quantidade do cátion de $\mathrm{Al}^{\top}$ (alumínio tetraédrico) existente na hornblenda (Tab. 4). De acordo com os resultados analíticos de oito amostras, o valor médio foi de 4,21 \pm 0,19 kbar para a unidade ultramáfica e de 4,55 \pm 0,33 kbar para o anfibolito.

\subsection{Litoquímica de elementos maiores e traço}

Os dados de química de rocha total (43 análises, sendo 38 nos litotipos ultramáfico e 5 no anfibolito) para elementos maiores e traço (Tab. 7 do material suplementar) foram utilizados para analisar o comportamento geoquímico dos distintos tipos litológicos, observar as propriedades geoquímicas do magma fonte e seu comportamento no decurso do processo de cristalização fracionada. Em função das concentrações de $\mathrm{SiO}_{2}$ as rochas analisadas foram classificadas como básicas e ultrabásicas com teores variando entre 34,75 a $46,69 \%$ para os peridotitos, 39,18 a 56,09\% para piroxenitos e 50,56 a 53,25\% para o anfibolito. Os valores de mg\# variam de 79,83 a $91,35 \%$ para os peridotitos, 79,51 a $84,76 \%$ para os piroxenitos e 75,27 a $81,33 \%$ para o anfibolito, caracterizando a natureza primitiva desse corpo.

Conforme demonstrado no diagrama bivariante para os demais elementos maiores em função do MgO (Fig. 14), observa-se que os teores de $\mathrm{SiO}_{2}$ são inversamente proporcionais à presença de forsterita/crisólita, alcançando seu ponto máximo no fracionamento dos piroxenitos e mantendo-se constante durante a evolução do anfibolito. O conteúdo de FeOt, calculado como $\mathrm{Fe}_{2} \mathrm{O}_{3^{\prime}}$ exibe um decrescimento das rochas mais primitivas para as unidades menos primitivas, resultado da menor proporção de minerais ferromagnesianos cumuláticos. Os teores de $\mathrm{CaO}$ e $\mathrm{Al}_{2} \mathrm{O}_{3}$ são semelhantes e crescem com a redução da participação da forsterita/crisólita como fase cumulática e aumento da participação da magnésio-hornblenda e augita como fases 


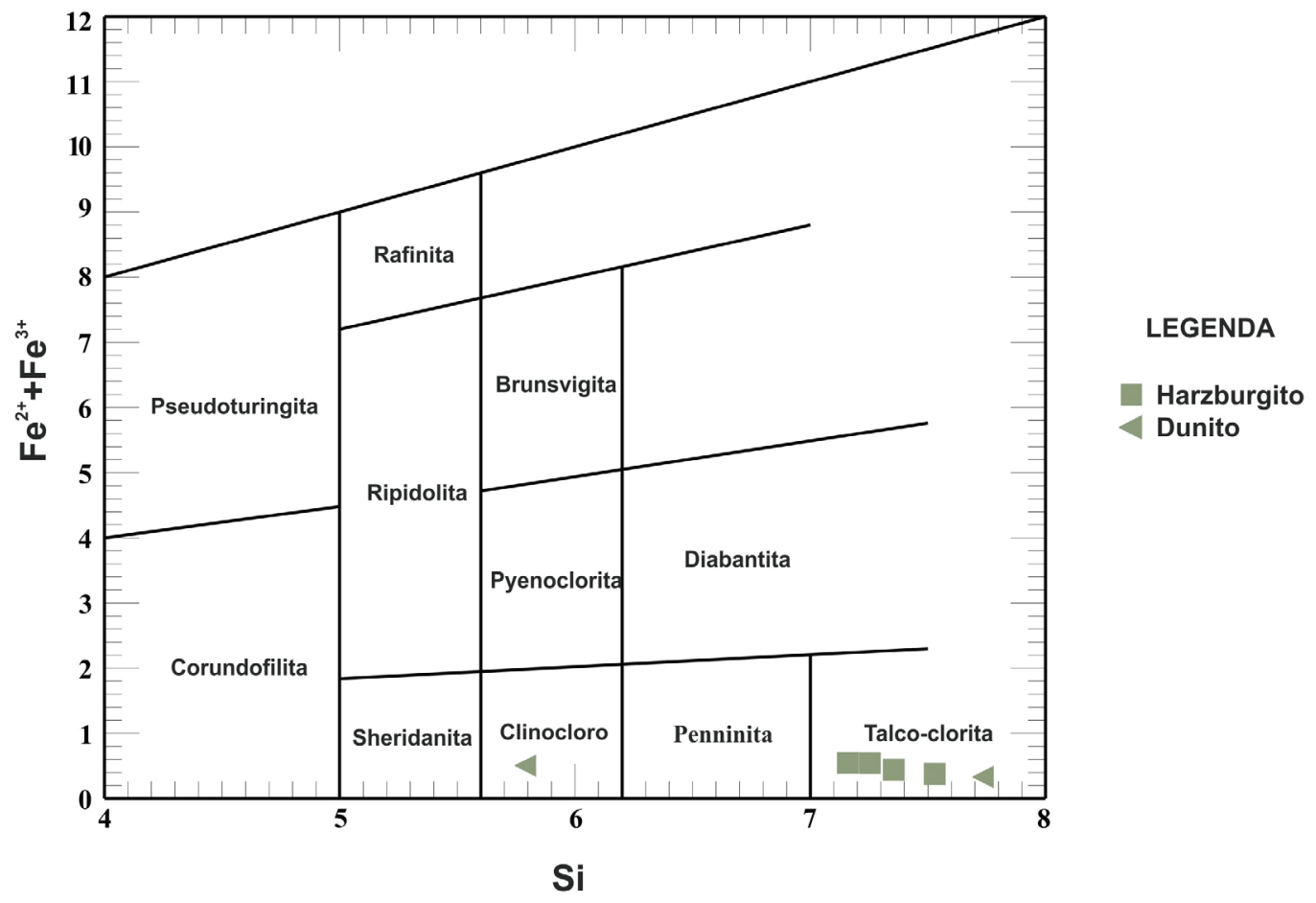

Figura 13. Diagrama de classificação da clorita, modificado de Deer et al. (1992). Figure 13. Chlorite classification diagram, modified from Deer et al. (1992).

Tabela 2. Temperaturas calculadas com base no geotermômetro cpx - líquido e valor médio para a unidade ultramáfica. Table 2. Calculated temperatures based on cpx - liquid geothermometer and average value for the ultramafic unit.

\begin{tabular}{ccc}
\hline Amostra (par opx-cpx) & Litotipo & Putirka (2008; eq. 33) \\
\hline CM02-06 & Websterito & $\mathrm{T}\left({ }^{\circ} \mathrm{C}\right)$ \\
CM02-06 & Websterito & 1175,6 \\
CM04-18 & Lherzolito & 1210,2 \\
CM04-18 & Lherzolito & 1231,6 \\
Média (4 amostras) & & 1249,5 \\
\hline
\end{tabular}

Tabela 3. Temperaturas calculadas com base no geotermômetro pl - amp e valor médio para o anfibolito. Table 3. Calculated temperatures based on $\mathrm{pl}$ - amp geothermometer and average value for the amphibolite.

\begin{tabular}{ccc}
\hline Amostra (par pl-amp) & Litotipo & Blundy \& Holland (1990) \\
\hline & & $\mathrm{T}\left({ }^{\circ} \mathrm{C}\right)$ \\
CM02-02 & Anfibolito & 874,78 \\
CM02-02 & Anfibolito & 881,01 \\
CM02-02 & Anfibolito & 855,55 \\
CM02-02 & Anfibolito & 857,52 \\
CM02-02 & Anfibolito & 876,91 \\
Média (5 amostras) & & $869,15 \pm 10,51$ \\
\hline
\end{tabular}


Tabela 4. Pressões calculadas (kbar) baseado no geobarômetro de $\mathrm{Al}^{\top}$ em hornblenda. Table 4. Calculated pressures (kbar) based on the hornblende Al ${ }^{\top}$ geobarometer.

\begin{tabular}{cccc}
\hline Amostra (Hbl) & Litotipo & $\mathrm{Al}^{\mathrm{T}}$ & Pressão $( \pm 1$ kbar $)$ \\
\hline CM04-11 & Hornblenda Piroxenito & 1,66 & 4,61 \\
CM04-11 & Hornblenda Piroxenito & 1,68 & 4,74 \\
CM04-11 & Hornblenda Piroxenito & 1,74 & 5,04 \\
CM04-11 & Hornblenda Piroxenito & 1,63 & 4,44 \\
\hline Média (4 amostras) & & $1,68 \pm 0,03$ & $4,21 \pm 0,19$ \\
\hline CM02-02 & Anfibolito & 1,69 & 4,78 \\
CM02-02 & Anfibolito & 1,71 & 4,87 \\
CM02-02 & Anfibolito & 1,53 & 3,88 \\
CM02-02 & Anfibolito & 1,67 & 4,65 \\
\hline Média (4 amostras) & & $1,65 \pm 0,06$ & $4,55 \pm 0,33$ \\
\hline
\end{tabular}

pós-cumuláticas nos piroxenitos. Esses óxidos apresentam maior concentração onde acumulou mais plagioclásio no anfibolito de protólito máfico. $\mathrm{O} \mathrm{TiO}_{2}$ mantém um comportamento relativamente constante nos peridotitos para os porções mais máficas, indicando, assim, um pequeno ou ausente fracionamento da titanita/ esfeno. $\mathrm{O} \mathrm{Na} 2 \mathrm{O}$ apresenta valores crescentes à medida que a cristalização avança, apresentando valores mais expressivos no litotipo de protólito máfico, devido à acumulação do plagioclásio. $\mathrm{O} \mathrm{K}_{2} \mathrm{O}$ exibe trend semelhante, mas demonstra dispersão em algumas amostras. Há valores de $\mathrm{K}_{2} \mathrm{O}$ relativamente anômalos nas amostras CM2-04 (harzburgito) com 0,75\% e CM2-06 (websterito) com 0,9\%. Os teores de $\mathrm{Co}, \mathrm{Cu}$, $\mathrm{Cr}$ e Ni (Fig. 15) apresentam trends típicos de acumulação nas olivinas, evidenciando um comportamento compatível desses elementos com as rochas ultramáficas. Os altos valores de $\mathrm{Ni}$ em comparação aos baixos valores de $\mathrm{Cu}$ provavelmente estão relacionados à presença de Ni na estrutura da olivina e não a sulfetos. Os altos valores de Sr (Fig. 15) no anfibolito, em comparação às ultramáficas, são decorrentes do acúmulo do plagioclásio nas rochas mais evoluídas. Comportamentos semelhantes ocorrem entre o $\mathrm{Y}$ e $\mathrm{Zr}$ que mostram valores relativamente estáveis para as unidades estudadas.

Nos diagramas biavariantes de Pearce (1970), a partir da relação das razões $\mathrm{Fe}_{2} \mathrm{O}_{3}+\mathrm{MgO} /$ $\mathrm{Al}_{2} \mathrm{O}_{3}$ versus $\mathrm{SiO}_{2} / \mathrm{Al}_{2} \mathrm{O}_{3}$ e CaO/Al $\mathrm{O}_{3}$ versus $\mathrm{SiO}_{2} /$
$\mathrm{Al}_{2} \mathrm{O}_{3}$ (Fig. 16A, 16B), o valor da inclinação da razão foi de 1,23 plotando no campo entre olivina e piroxênio e 0,01 plotando no campo da olivina, respectivamente.

Os teores de elementos terras raras dos litotipos são mostrados na figura 17 , normalizados em relação aos valores condríticos de McDonough \& Sun (1995). De maneira geral, as curvas demonstraram um enriquecimento discreto nos elementos terras raras leves (ETRL) com relação aos pesados (ETRP), os quais se apresentam praticamente não fracionados. As rochas ultramáficas estudadas exibem um discreto fracionamento do ETRL, com exceção do La, em comparação aos pesados. Comparando os peridotitos (Fig. 17A) com os piroxenitos (Fig. 17B) não é observado um fracionamento significativo entre esses grupos.

As razões [La/Lu]n para os peridotitos apresentam valores entre 3,64 a 3,83, enquanto que para os piroxenitos, os valores das razões variam entre 2,21 a 9,82.

$\mathrm{Na}$ rocha anfibolítica (Fig. 17C) não é observado um enriquecimento dos ETRL em relação aos intermediários e aos pesados. Além disso, em comparação com as rochas ultramáficas, essas rochas demonstram um menor fracionamento dos elementos terras raras. As razões [La/Lu]n variam entre 3,22 a 3,64 .

Nos peridotitos e em alguns piroxenitos há uma anomalia negativa de Eu, demonstrando a presença de plagioclásio no líquido, ao passo que 

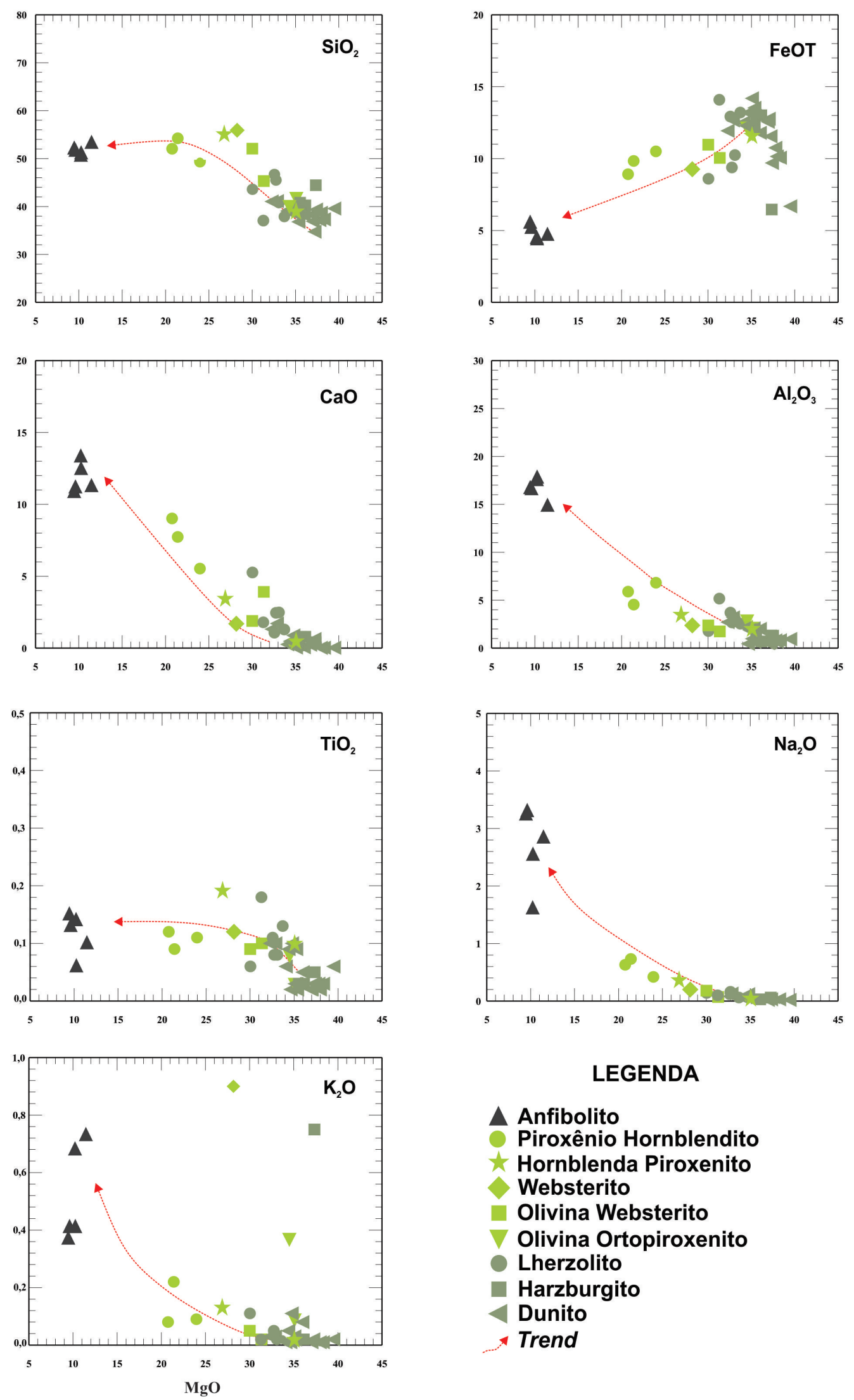

\section{LEGENDA}

$\triangle$ Anfibolito

Piroxênio Hornblendito

Hornblenda Piroxenito

Websterito

Olivina Websterito

Olivina Ortopiroxenito

Lherzolito

Harzburgito

Dunito

Trend

Figura 14. Diagramas de variação dos óxidos de elementos maiores versus $\mathrm{MgO}$ (\% peso).

Figure 14. Variation diagrams for major oxides versus $\mathrm{MgO}$ (weight \%). 

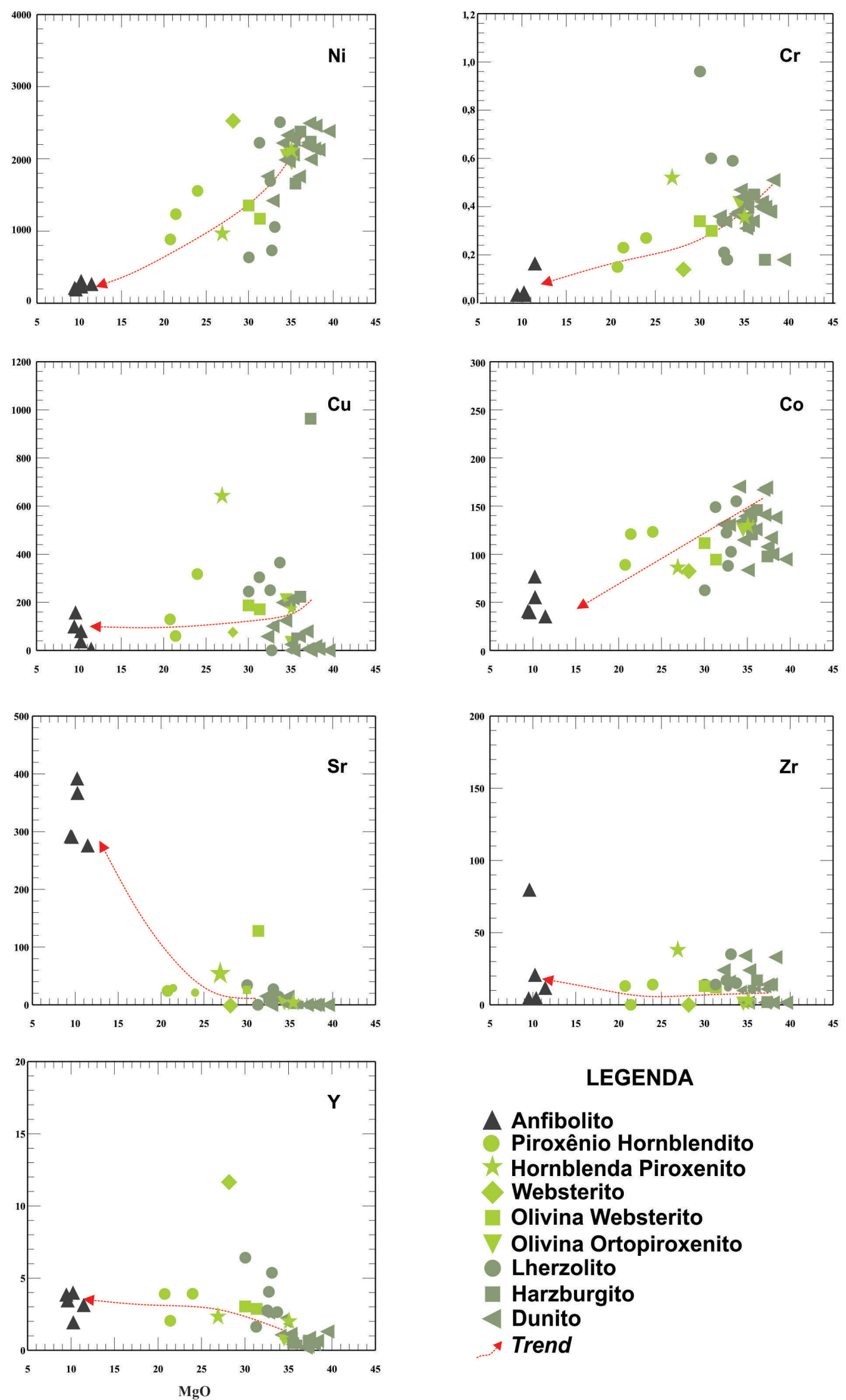

\section{LEGENDA}

$\triangle$ Anfibolito

Piroxênio Hornblendito

Hornblenda Piroxenito

Websterito

Olivina Websterito

Olivina Ortopiroxenito

Lherzolito

Harzburgito

Dunito

Trend

Figura 15. Diagramas de variação dos elementos traço (ppm) versus $\mathrm{MgO}$ (\% em peso).

Figure 15. Variation diagrams for trace elements ( $p p m)$ versus $\mathrm{MgO}$ (weight\%). 

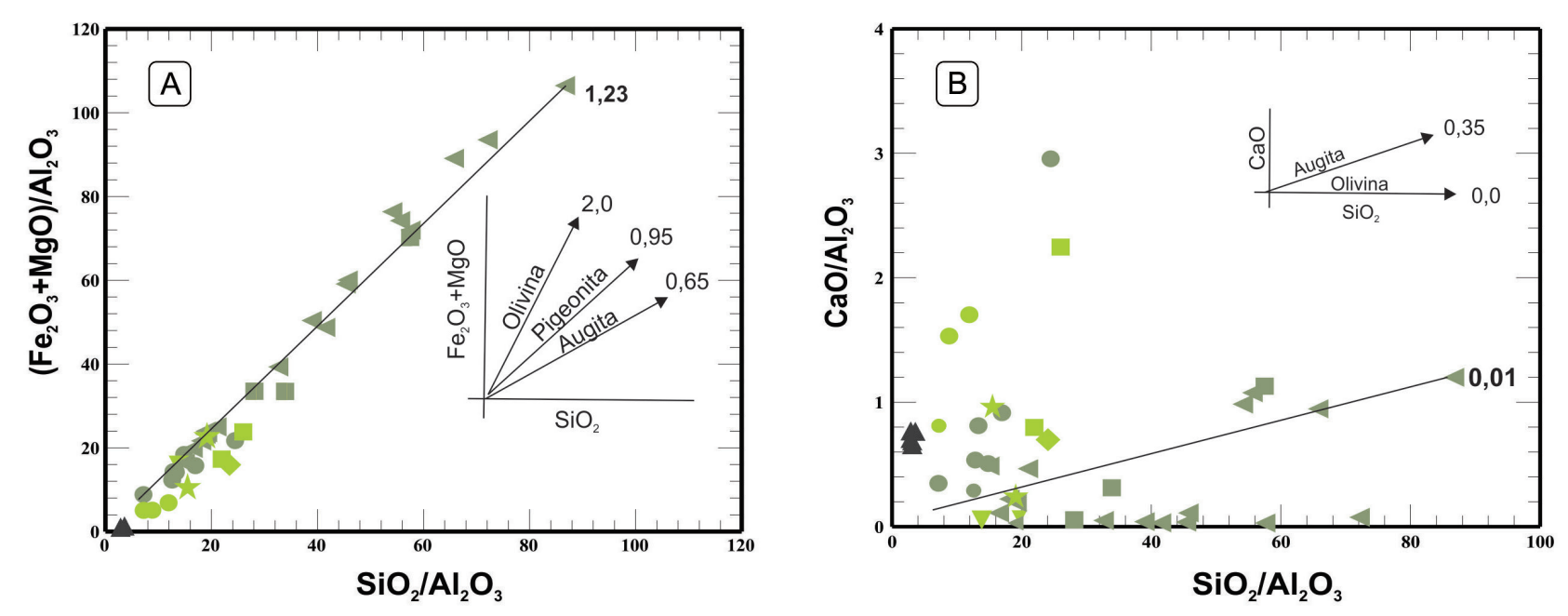

\section{LEGENDA}
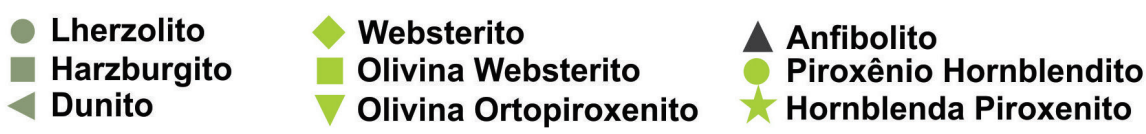

Figura 16. Diagramas binários modificados de Pearce (1970) para demonstrar as fases controladoras do fracionamento magmático. A) Diagrama $\left(\mathrm{Fe}_{2} \mathrm{O}_{3}+\mathrm{MgO}\right) / \mathrm{Al}_{2} \mathrm{O}_{0}$ mostrando o ortopiroxênio como o controlador do fracionamento; $\mathrm{B}$ ) Digrama $\mathrm{CaO} / \mathrm{Al}_{2} \mathrm{O}_{3}$ mostrando a olivina como controladora do fracionamento.

Figure 16. Variation diagrams modified from Pearce (1970) to demonstrate the construction phases of the magmatic fractionation. A) $\left(\mathrm{Fe}_{2} \mathrm{O}_{3}+\mathrm{MgO}\right) / \mathrm{Al}_{2} \mathrm{O}_{3}$ diagram showing the orthopyroxene as the fractionation controller; $\left.\mathrm{B}\right) \mathrm{CaO} / \mathrm{Al}_{2} \mathrm{O}_{3}$ diagram showing the olivine as the fractionation controller.
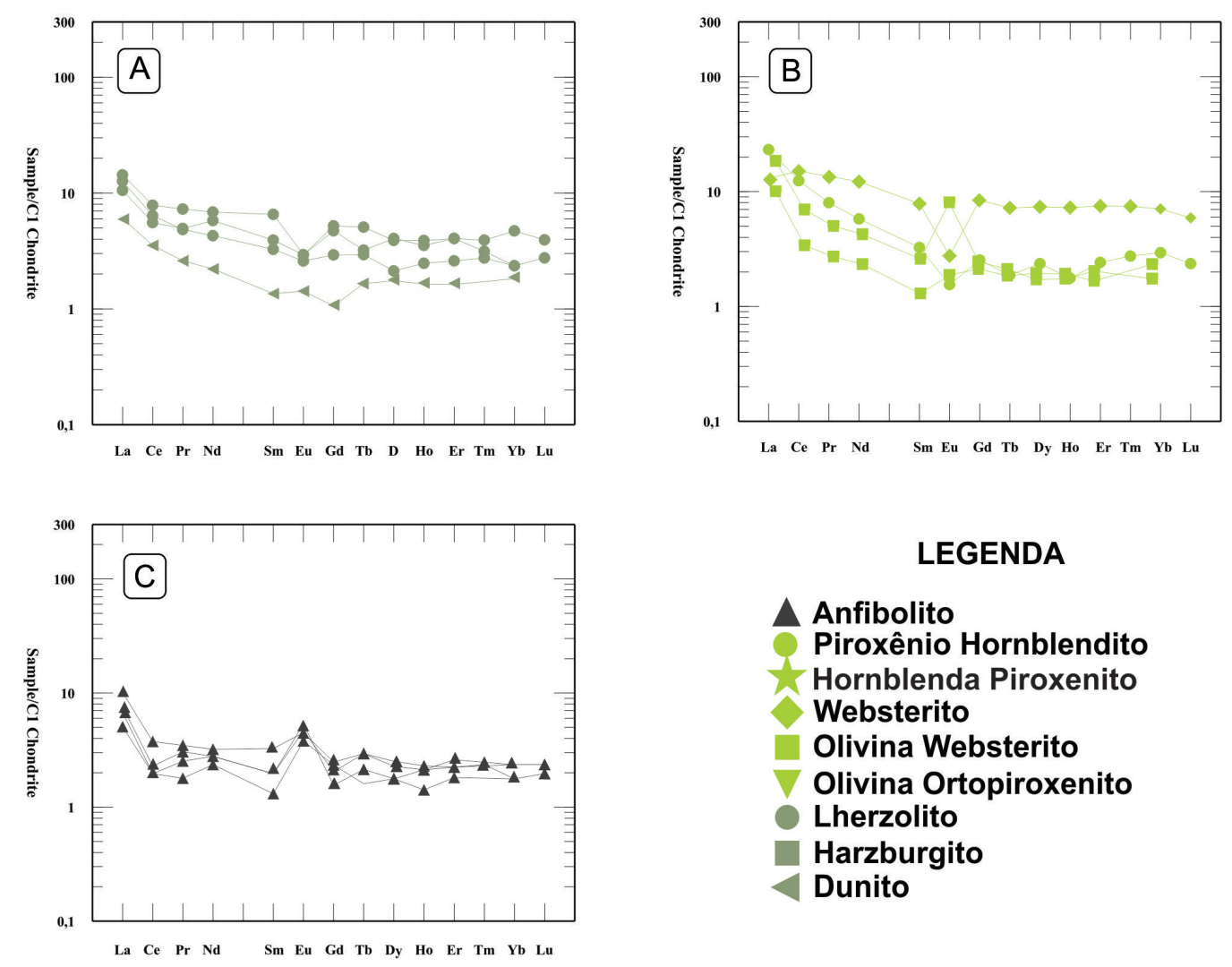

\section{LEGENDA}

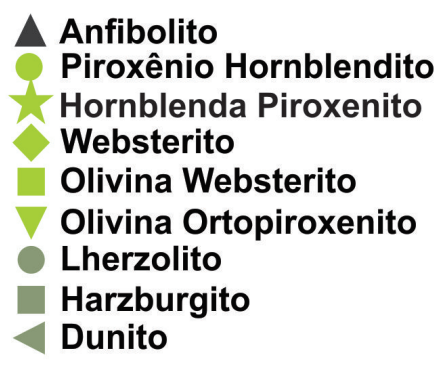

Figura 17. Diagrama normalizado do condrito para elementos de terras raras, os valores de normalização de McDonough e Sun (1995). A) Peridotitos; B) Piroxenitos; C) Anfibolito.

Figure 17. Chondrite normalized diagram for rare earth elements, normalizing values from McDonough and Sun (1995). A) Peridotites; B) Pyroxenites; C) Amphibolite. 

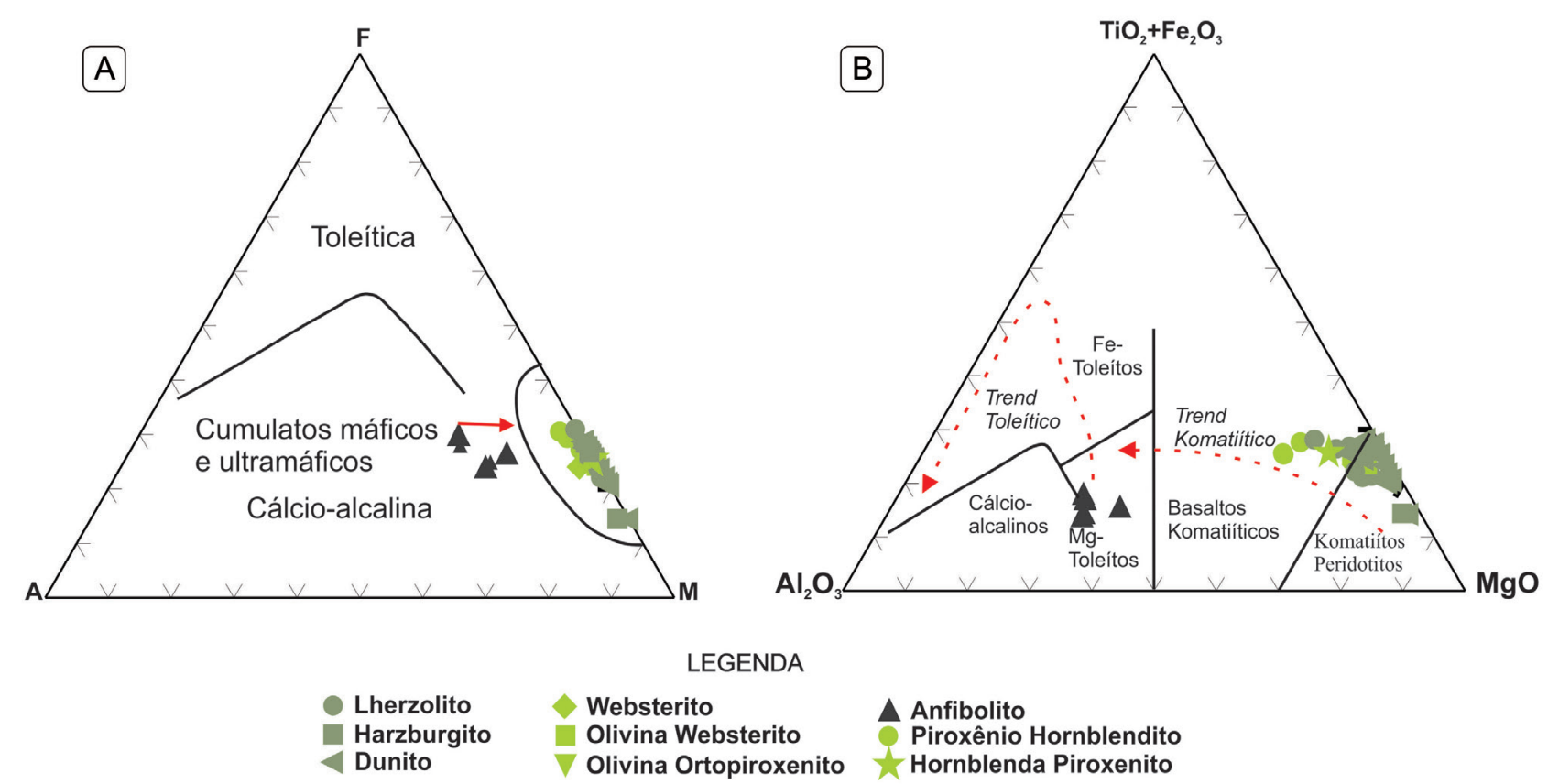

Figura 18. Diagramas de discriminação petrogenética. A) Diagrama AFM modificado de Irvine \& Baragar (1971); B) Diagrama tectônico modificado de Jensen (1976) pra as rochas estudadas.

Figure 18. Petrogenetic discrimination diagrams. A) AFM diagram modified from Irvine \& Baragar (1971); B) Tectonic diagram (modified from Jensen, 1976) for the studied rocks.

no anfibolito é observado uma anomalia positiva de Eu. Isso demonstra o particionamento deste elemento e acúmulo do plagioclásio durante a cristalização do protólito máfico do anfibolito.

No diagrama AFM proposto por Irvine \& Baragar (1971), as rochas ultramáficas plotam próximas ao vértice $\mathrm{MgO}$ (Fig. 18A), caracterizadas por sua natureza cumulática com um discreto enriquecimento em álcalis, enquanto que o anfibolito exibe um maior enriquecimento nesses elementos. No diagrama de Jensen (1976), as amostras ultramáficas plotam no campo dos peridotitos e basaltos komatiíticos, onde seguem um trend komatítico e alcançam a área dos Mg-Toleítos com o anfibolito (Fig. 18B).

\section{Discussão dos resultados}

O corpo máfico-ultramáfico apresenta um bandamento cíclico, sobretudo, entre os peridotitos. Foi identificada uma possível estratificação em fase, sendo definida pela variação na identidade dos minerais cumuláticos que variam de olivina e espinélio nos peridotitos mais primitivos a ortopiroxênio nos piroxenitos e plagioclásio na porção máfica.
Movimentos tectônicos sugerem deslocamento e basculamento do corpo, colocando rochas mais diferenciadas na base e rochas mais primitivas no topo. Processos secundários, principalmente nos locais próximos às zonas de cisalhamento, podem ter gerado feições de serpentinização e subordinadamente, talcificação, carbonatação e, especialmente, de anfibolitização da porção máfica, esses processos podem estar relacionados a metamorfismo dinâmico local, possivelmente associado ao metamorfismo orogênico regional paleoproterozoico.

$\mathrm{Na}$ análise petrográfica foi observado que as rochas da unidade ultramáfica exibem composição modal mais diversificada em comparação à rocha da porção máfica com composição modal monótona e, atualmente, anfibolitizada. Foi possível observar a seguinte ordem de cristalização primária nas rochas da porção ultramáfica: forsterita/crisólita - espinélio - esntatita - augita - magnésio hornblenda. As paragêneses de baixo grau metamórfico (serpentina + talco + clorita) nas rochas últramáficas demonstram que esta porção do corpo foi afetada por processos pós-magmáticos 
de baixo grau, chegando a formar serpentinito. $\mathrm{Na}$ porção máfica, o anfibolito apresenta paragênese mineral formada por labradorita magnésio hornblenda - diopsídio. Essa trama mineralógica da rocha anfibolítica exibe reação do anfibólio para a formação do clinopiroxênio e plagioclásio. Conforme Bucher \& Grapes (2011), essa reação leva a cristalização de plagioclásio mais rico em Ca (labradorita), compatível com os resultados de química mineral para o plagioclásio do anfibolito. A orientação preferencial presente na rocha (textura nematoblástica), ausência de maclas polissintéticas no plagioclásio e formação de kink band em enstatita, somada a cristalização de diopsídio sugere que o protólito máfico foi submetido a processos tectônicos deformacionais sob condições de temperatura e pressão compatíveis com as fácies anfibolito superior a granulito inferior.

Segundo Gill (2010), peridotitos alpinos apresentam associações íntimas com rochas de alto grau, como rochas granulíticas, contudo, os teores de forsterita na olivina variam de 81,2 a $91,9 \%$, estando dentro dos limites analisados para os complexos estratificados e complexos concêntricos (tipo Alaska), descartando a hipótese de peridotitos alpinos, pois estes variam de 88 a 94\% para os complexos alpinos harzburgíticos e de 87 a 94\% nos complexos alpinos Iherzolíticos, conforme classificação de Jackson \& Thayer (1972).

Os altos valores de $\mathrm{Al}_{2} \mathrm{O}_{3}$ em alguns piroxênios, provavelmente, estão relacionados à presença de espinélio nessas rochas e não a condições de alta pressão.

Nos dados geotermobarométricos, as temperaturas calculadas para o par anfibólioplagioclásio no anfibolito exibe temperatura média em torno de $869^{\circ} \mathrm{C}$, indicando uma temperatura de reequilíbrio metamórfico. A temperatura de $1220,90^{\circ} \mathrm{C}$ do clinopiroxênio líquido sugere temperatura de cristalização da unidade ultramáfica. 0 dado médio barométrico variando de 4,21 a 4,55 kbar para o hornblenda piroxenito e anfibolito, respectivamente, com base no teor de $\mathrm{Al}^{\top}$ (Al tetraédrico) em hornblenda, é compatível com os dados de pressão de reequilíbrio metamórfico associado à orogênese paleoproterozoica. Além disso, o corpo máfico- ultramáfico é encaixado em rocha de natureza granulítica que se encontra reequilibrada na faixa de pressão entre 5 e 7 kbar (Barbosa, 1986; Barbosa \& Fonteilles, 1991; Barbosa \& Sabaté, 2004), corroborando com o espectro calculado de temperatura e pressão.

No diagrama bivariante de Pearce (1970), foi possível confirmar olivina e ortopiroxênio como as principais fases controladoras da diferenciação por cristalização fracionada. Além disso, os diagramas demonstram que não houve uma alteração significativa das rochas, corroborando com os diagramas de Fenner para elementos maiores e traço. Dessa forma, é possível inferir que os eventos pós-magmáticos podem ter influenciado na composição e na alteração do corpo máfico-ultramáfico, em maior ou menor grau, mas não interferiram, significativamente, na química, de natureza cumulática, dessas rochas. Ademais, o comportamento de alguns elementos traço, como $\mathrm{Ni}, \mathrm{Sr}$, acumulados em olivina e plagioclásio, respectivamente, demonstram trends típicos de rochas cumuláticas.

Valores acima de $50 \%$ de $\mathrm{SiO}_{2}$ para rochas ultramáficas como apresentado por algumas das amostras estudadas no presente trabalho, confirmam a importância do fracionamento do ortopiroxênio (enstatita) em cumulados ultramáficos (Gill, 2010). Da mesma forma, a presença constante de ortopiroxênio nos variados tipos litológicos que formam o corpo sugere que o magma original tenha sido saturado em sílica, possivelmente de natureza toleítica (Abram, 1993).

Alguns autores, como Campbell (1985) e Huppert \& Sparks (1985), sugerem que a presença de ortopiroxênio em rocha máfica-ultramáfica dessa natureza está relacionada a processos de contaminação crustal.

O padrão mais primitivo com um menor fracionamento de elementos terras raras para a rocha anfibolítica, em comparação às rochas da unidade ultramáfica, pode ser explicado pelo comportamento incompatível dos ETR, os quais se concentram preferencialmente no líquido póscumulático (Haskin \& Haskin, 1968).

Os padrões de elementos terras raras são semelhantes aos padrões obtidos por rochas toleíticas continentais não orogênicas. Os dados 
divergem dos padrões de elementos terras raras do tipo Alpino, os quais apresentam um empobrecimento de ETRL em relação ETRP, ao contrário dos elementos terras raras de complexos estratificados não orogênicos (Abram, 1993). Além disso, a predominância de anomalias negativas de Eu em rochas ultramáficas sugere natureza toleítica para o corpo. O baixo fracionamento dos ETRP sugere que o corpo máfico-ultramáfico da Fazenda Campo do Meio foi formado a partir da fusão parcial do manto primitivo, não alcançando a zona da granada.

As razões [La/Lu]n, em sua maioria, estão no mesmo espectro de variação dos complexos intrusivos toleíticos (Cullers \& Graf, 1984), o qual abrange um intervalo de 0,3 a 19,3.

\section{Conclusões}

O estudo realizado no corpo máficoultramáfico da Fazenda Campo do Meio, município de Marcionílio Souza, Bahia, permitiu esclarecer aspectos sobre a petrologia desse corpo, a partir de dados petrográficos, litoquímicos, de química mineral e geotermobarométricos. O corpo é caracterizado como de pequeno porte, encaixado nos terrenos granulíticos do Bloco Jequié.

A estratigrafia do corpo é formada por rochas ultramáficas no topo e anfibolítica de protólito máfico na base, sugerindo que foram submetidas a esforços tectônicos. A partir da composição mineralógica modal, as rochas ultramáficas foram classificadas em peridotitos (dunito, harzburgito e Iherzolito), piroxenitos (olivina ortopiroxenito, olivina websterito, websterito, hornblenda piroxenito) e, por fim, piroxênio hornblendito. Na porção máfica foi caracterizado um piroxênio hornblenda gabro anfibolitizado, possibilitando, assim, observar uma composição mais diversificada entre as rochas ultramáficas.

No estudo petrográfico foram observadas feições que permitiram sugerir a presença de fluidos tardios, transformando parcial e/ ou totalmente a mineralogia primária dessas rochas. Contudo, não houve obliteração dos aspectos texturais de natureza ígnea cumulática, marcada pela presença de olivina e ortopiroxênio que se comportam tanto como cumulados quanto como pós-cumulados em peridotitos e piroxenitos. O litotipo máfico foi mais afetado pelos processos deformacionais e metamórficos, evidenciados pela intensa orientação dos minerais e formação de diopsídio. Nessa rocha, a hornblenda e, principalmente, o plagioclásio, corroborado pelos padrões de Sr, foram fases cumuláticas recristalizadas em fácies anfibolito alto a granulito baixo pelos processos pósmagmáticos mencionados anteriormente.

As análises litoquímicas de elementos maiores e traço confirmam que as rochas não foram quimicamente afetadas, de forma significativa, pelos processos pós-magmáticos, permitindo, assim, observar o processo de acumulação em que aforsterita/crisólita e a enstatita foram as principais fases minerais que controlaram o fracionamento magmático da unidade ultramáfica, seguida pelo fracionamento do plagioclásio na unidade máfica. Por fim, é sugerido, através dos estudos realizados, que o corpo máfico-ultramáfico da Fazenda Campo do Meio é compatível com uma intrusão acamadada de pequeno porte, formada por cristalização fracionada, de natureza toleítica continental compatível com complexos importantes descritos na literatura como Bushveld, Stillwater e Skaegaard.

Agradecimentos. Agradecemos ao Conselho Nacional de Desenvolvimento Científico e Tecnológico (CNPq) pelo apoio através da concessão de bolsa da primeira autora e apoio financeiro (Processo CNPq 47690187/2013-8). As autoras também agradecem à Companhia Baiana de Pesquisa Mineral (CBPM) por todo apoio logístico e técnico.

\section{Referências}

Abram, M.B. 1993. O corpo máfico-ultramáfico da fazenda Mirabela, Ipiaú-BA: Caracterização petrográfica, geoquímica, tipologia e implicações metalogenéticas. Salvador, 137p. Dissertação de mestrado, Programa de Pós-Graduação em Geologia, Instituto de Geociências, Universidade Federal da Bahia. Almeida, F.F.M. 1977. O Cráton do São Francisco. Revista Brasileira de Geociências, 7(4): 349- 
364.

Barbosa, J., Martin, H. \& Peucat, J.J. 2004. Paleoproterozoic dome-forming structures related to granulite-facies metamorphism, Jequié Block, Bahia, Brazil: petrogenetic approaches. Precambrian Research, 135: 105-131.

Barbosa, J.S.F. \& Fonteilles, M. 1991. Síntese sobre o metamorfismo da região granulítica do sul da Bahia - Brasil. Revista Brasileira de Geociências, 21(4): 328-341.

Barbosa, J.S.F \& Sabaté, P. 2003. Colagem paleoproterozoica de placas arqueanas no Cráton do São Francisco na Bahia. Revista Brasileira de Geociências, 31 (supl.): 7-14.

Barbosa, J.S.F. \& Sabaté, P. 2002. Geological features and the paleoproterozoic collision of four archean crustal segments of the Sao Francisco Craton, Bahia, Brazil. A synthesis. Anais da Academia Brasileira de Ciências, 74(2): 343-359.

Barbosa, J.S.F. \& Sabaté, P. 2004. Archean and paleoproterozoic crust of the Sao Francisco Craton, Bahia, Brazil: geodynamic features. Precambrian Research, 133: 1-27.

Barbosa, J.S.F., Cruz, S.C.P \& Souza, J.S. 2012. Terrenos metamórficos do embasamento. In: Barbosa, J.S.F., Mascarenhas J. \& Gomes, L.C.C. (Ed.). Geologia da Bahia. Pesquisa e Atualização. V. 1, Salvador, Companhia Baiana de Pesquisa Mineral - CBPM, p. 101-201.

Barbosa, J.S.F., Sabaté, P. \& Marinho, M.M., 2003. Cráton São Francisco na Bahia: Uma síntese. Revista Brasileira de Geociências, 33(1): 3-6.

Barbosa, J., Nicollet, C., Leite C., Kienast, J.R., Reinhardt, F.A \& Macedo, E.P. 2006. Hercynitequartz-bearing granulites from Brejões Dome area, Jequié Block, Bahia, Brazil: Influence of charnockite intrusion on granulite facies metamorphism. Lithos, 92: 537-556.

Barbosa, J.S.F. 1986. Constitution lithologique et metamorphique de la region granulitique du sud de Bahia-Brésil. Paris, 401p. Tese de Doutorado, Académie de Paris, Université Pierre et Marie Curie.

Blundy, J.D. \& Holland, T.J.B. 1990. Calcic amphibole equilibria and a new amphiboleplagioclase geothermometer. Contributions to Mineralogy and Petrology, 104: 208-224.
Brito, R.S.C. 2000. Geologia e petrologia do sill máfico ultramáfico do rio Jacaré - Bahia e estudo das mineralizações de Fe-Ti-V e platinóides associadas. Brasília, 384p. Tese de doutorado, Programa de Pós-Graduação em Geologia, Instituto de Geociências, Universidade de Brasília.

Bryan, S.E., Ernst, R.E. 2008. Revised definition of large igneous provinces (LIPS). Earth-Science Reviews, 86: 175-202.

Bucher, K. \& Frey, M. 1994. Petrogenesis of metamorphic rocks. Berlin, Springer, 318p.

Bucher, K. \& Grapes, R. 2011. Petrogenesis of metamorphic rocks. Berlin, Springer-Verlag, 428p.

Campbell, I.H. 1985. The difference between oceanic and continental tholeiites: a fluid dynamic explanation. Contributions to Mineralogy and Petrology, 91: 37-43.

Campbell, I.H. 1996. Fluid dynamic processes in basalt magma chambers. In: Cawthorn, R.G. (Ed.). Layered Intrusions. Amsterdam, Elsevier Science Publishers, p. 45-76.

Coutinho, J., Kräutner, H., Sassi, F., Schmid, R. \& Sen, S. 2007. Amphibolite and granulite. In: Fettes, D. \& Desmons, J. (Ed.). Metamorphic rocks, a classification and glossary of terms. New York, Cambridge University Press, p. 5157.

Couto, P.A., Sampaio, A.R., Gil, C.A.A., Loureiro, H.C., Arcanjo, J.B., Fernandes Filho, J., Guimarães, J.T., Campêlo, R., Mascarenhas, J.F., Bruni, D.C., Toledo, L.A. 1978. Projeto serra da Jacobina: geologia e prospecção geoquímica. Relatório final. Salvador, CPRM, $416 p$.

Cruz, M.J.M. 1989. Le massif du Rio Piau: une intrusion de nature gabbroique et anortositique dans les terrains granulitiques du noyau Jequié-Bahia-Brésil. Paris, 280p. Tese Doutorado, Université Pierre et Marie Curie.

Cullers, R.L. \& Graf, J.L. 1984. Rare earth elements in igneous rocks of the continental crust: predominantly basic and ultrabasic rocks. In: Henderson, P. (Ed.) Rare Earth Element Geochemistry. Amsterdam, Elsevier Science Publishers, v. 2, p. 237-274.

Deer, W.A., Howie, R.A. \& Zussman, J. 1992. 
Minerais contituintes de rochas. Lisboa, Fundação Calouste Gulbenkian, 727p.

Ernst, R.E. 2007. Mafic-ultramafic large igneous provinces (LIPs): Importance of the premesozoic record. Episodes, 30(2): 108-114.

Ferreira Filho, C.F., Cunha, J.C., Cunha, E.M., Canela, J.H.C. 2013. Depósito de níquel-cobre sulfetado da Santa Rita, Itagibá-Bahia-Brasil. In: Viana, I.A. (Ed.). Salvador, Série Arquivos Abertos, Companhia Baiana de Pesquisa Mineral - CBPM, 64p.

Gill, R. 2010. Igneous rocks and processes a practical guide. Chichester, Bookman, 427p.

Haskin, L.A. \& Haskin, M.A. 1968. Rare-earth elements in the Skaergaard intrusion. Geochimica et Cosmochimica Acta, 32: 433447.

Hollister, L.S., Grissom, G.C., Peters, E.K-, Stowell, H.H. \& Sisson, V.B. 1987. Confirmation of the empirical correlation of $\mathrm{Al}$ in hornblende with pressure of solidification of calc-alkaline plutons. American Mineralogist, 72: 231-239.

Huppert, H.E., Sparks, R.S.J. 1985. Cooling and contamination of mafic and ultramafic magmas during ascent through continental crust. Earth and Planetary Letters, 74: 371386.

Irvine, T.N. \& Baragar, W. 1971. A guide to the chemical classification of the common volcanic rocks. Canadian Journal Earth Science, 8: 523-548.

Jackson, E.D. \& Thayer, T.P. 1972. Some criteria for distinguishing between stratiform, concentric and alpine peridotite-gabbro complexes. In: INTERNACIONAL. GEOLOGICAL CONGRESS, 24., 1972, Montreal. Seção 2, p. 289-296.

Jensen, L.S. 1976. A new cation plot for classifying subalkalic volcanic rocks. Ontario Department of Mines, Miscellaneous Paper 66, 22p.

Le Maitre, R.W., Streckeisen, A., Zanettin, B., Le Bas, M.J., Bonin, B. \& Bateman, P. 2002. (Ed.). Igneous Rocks: A Classification and Glossary of Terms. New York, Cambridge University Press, 236p.

Leake, B.E., Wooolley, A.R., Arps, C.E.S., Birch, W.D., Gilbert, M.C., Grice, J.D., Hawthorne, F.C., Kato, A., Kisch, H.J., Krivovichev, V.G., Linthout, K., Laird, J., Mandarino, J.A.,
Maresch, W.V., Nickel, E.H., Rock, N.M.S., Schumacher, J.C., Smith, D.C., Stephenson, N.C.N., Ungaretti, L., Whittaker, E.J.W. \& Youzhi, G. 1997. Nomenclature of Amphiboles: Report of the subcommittee on amphiboles of the international mineralogical association commission on new minerals and minerals names. Mineralogical Magazine, 61: 295-321.

Macêdo, E.P. 2000. Geoquímica do maciço anortosítico de Carapussê, Itamari-BahiaBrasil. Salvador, 121p. Dissertação de Mestrado, Programa de Pós-Graduação em Geoquímica e Meio Ambiente, Instituto de Geociências, Universidade Federal da Bahia.

Marinho, M.M., Vidal, Ph., Alibert, C., Barbosa, J.S.F. \& Sabaté, P. 1992. Geochronology of the Jequié-Itabuna granulitic belt and the Contendas-Mirante Volcano-Sedimentary belt. In: Pedreira, A.J. (Ed.). Petrologic and geochronologic evolution of the oldest segments of the São Francisco Craton, Brazil. Salvador, Companhia Baiana de Pesquisa Mineral - CBPM, p. 29-55.

Marques, J.C. \& Ferreira Filho, C.F. 2003. The chromite deposit of the Ipueira-Medrado Sill, São Francisco Craton, Bahia State, Brazil. Economy Geology, 98: 87-108.

Mascarenhas, J.F. \& Garcia, T.W. 1989. Mapa geocronológico do Estado da Bahia: texto explicativo, escala 1:1.000.000. Salvador, SGM/SME, 186p.

McDonough, W.F. \& Sun, S-S. 1995. The composition of the Earth. Chemical Geology, 120: 223-253.

Menezes Leal, A.B., Barbosa, J.S.F. \& Gomes, L.C.C. 2012. Corpos Máficos-Ultramáficos do Estado da Bahia. In: Barbosa, J.S.F., Mascarenhas J. \& Gomes, L.C.C. Geologia da Bahia. Pesquisa e Atualização. V. 1, Salvador, Companhia Baiana de Pesquisa Mineral CBPM, p. 443-483.

Moraes, A.M.V., Veiga, P.M.O. 2008. Depósitos de Ferro-Titânio-Vanádio: Campo Alegre de Lourdes/Bahia. Salvador, Série Arquivos Abertos, Companhia Baiana de Pesquisa Mineral - CBPM, 50p.

Morimoto, M. 1990. Nomenclatura dos piroxênios. Revista Brasileira de Geociências, 20(1-4): 318-328. 
Namur, O., Abily, B., Boudreau, A.E., Blanchette, F., Bush, J.W.M., Ceuleneer, G., Charlier, B., Donaldson, C.H., Duchesne, J-C., Higgins, M.D., Morata, D., Nielsen, T.F.D., O'Driscoll, B., Pang, K.N., Peacock, T., Spandler, C.J, Toramaru, A. \& Veksler, I.V. 2015. Igneous layering in basaltic magma chambers. In: Charlier, B., Namur, O., Latypov, R., Tegner, C. (Ed.). Layered Intrusions. Springer Geology, Berlin, p. 75-152.

Oliveira, E.P. \& Knauer, L.G. 1993. Corpos máficos e ultramáficos do Cráton do São Francisco. In: Dominguez, J.M.L. \& Misi, A. (Ed.). O Cráton do São Francisco. Salvador, SBG/SGC/CNPq, p.119-136.

Pearce, T.H. 1970. Chemical variations in the Palisade Sill. Journal of Petrology, 11: 15-32.

Putirka, K.D. 2008. Thermometers and barometers for volcanic systems. Reviews in Mineralogy \& Geochemistry, 69: 61-120.

Richard, L.R. 1995. MinPet: Mineralogical and petrological data processing system, versão 2.02. MinPet Geological Software, Quebec, Canadá.

Sá, J.H., Garrido, I.A.A. \& Cruz, M.J.M. 2010. Depósitos de Ferro e Titânio na Região Sul da Bahia. Salvador, Série arquivos abertos, Companhia Baiana de Pesquisa Mineral CBPM, 72 p.

Santos, M.C.P. 2013. Geologia, petrografia, química mineral, litogeoquímica e potencial metalogenético do corpo máfico-ultramáfico de Catingal, distrito de Manoel Vitorino, Bahia. Salvador, 149p. Dissertação de Mestrado, Programa de Pós-graduação em Geologia, Instituto de Geociências, Universidade Federal da Bahia.

Santos, M.C.P. 2018. Petrologia e geoquímica das rochas metamáficas e metaultramáficas do município de Manoel Vitorino, povoado de Catingal, estado da Bahia. Salvador, 134p. Tese de Doutorado, Programa de Pós-graduação em Geologia, Instituto de Geociências, Universidade Federal da Bahia.
Soto, J.I. \& Soto, V.M. 1995. PTmafic: Software package for thermometry, barometry, and activity calculations in mafic rocks using an IBM-compatible computer. Computers \& Geosciences, 21(5): 619-652.

Streckeisen, A. 1976. To each plutonic rock its proper name. Earth-Science Reviews, 12: 133.

Wager, L.R., Brown, M. \& Wadsworth, W. J. 1960. Types of igneous cumulates. Jornal of Petrology, 1(1): 73-85.

Whitney, D.L. \& Evans, B.W. 2010. Abbreviations for names of rock-forming minerals. American Mineralogist, 95: 185-187.

Winter, J.D. 2014. Principles of Igneous and Metamorphic Petrology. England, Pearson, $737 p$.

Manuscrito 887 | Recebido em ago. de 2019 | Aceito em dez. de 2019 | Editor: Carlos A. Sommer 